\title{
Lean mass sparing in resistance-trained athletes during caloric restriction: the role of resistance training volume
}

\author{
C. Roth ${ }^{1}$ (1) B. J. Schoenfeld ${ }^{2} \cdot$ M. Behringer ${ }^{1}$
}

Received: 27 September 2021 / Accepted: 11 January 2022 / Published online: 11 February 2022

(c) The Author(s) 2022

\begin{abstract}
Many sports employ caloric restriction (CR) to reduce athletes' body mass. During these phases, resistance training (RT) volume is often reduced to accommodate recovery demands. Since RT volume is a well-known anabolic stimulus, this review investigates whether a higher training volume helps to spare lean mass during CR. A total of 15 studies met inclusion criteria. The extracted data allowed calculation of total tonnage lifted (repetitions $\times$ sets $\times$ intensity load) or weekly sets per muscle group for only 4 of the 15 studies, with RT volume being highly dependent on the examined muscle group as well as weekly training frequency per muscle group. Studies involving high RT volume programs ( $\geq 10$ weekly sets per muscle group) revealed low-to-no (mostly female) lean mass loss. Additionally, studies increasing RT volume during CR over time appeared to demonstrate no-to-low lean mass loss when compared to studies reducing RT volume. Since data regarding RT variables applied were incomplete in most of the included studies, evidence is insufficient to conclude that a higher RT volume is better suited to spare lean mass during CR, although data seem to favor higher volumes in female athletes during CR. Moreover, the data appear to suggest that increasing RT volume during CR over time might be more effective in ameliorating CR-induced atrophy in both male and female resistance-trained athletes when compared to studies reducing RT volume. The effects of CR on lean mass sparing seem to be mediated by training experience, pre-diet volume, and energy deficit, with, on average, women tending to spare more lean mass than men. Potential explanatory mechanisms for enhanced lean mass sparing include a preserved endocrine milieu as well as heightened anabolic signaling.
\end{abstract}

Keywords Protein synthesis $\cdot$ Protein degradation $\cdot$ Intracellular pathways $\cdot$ Weight loss $\cdot$ Weight training $\cdot$ Anabolism

\section{Introduction}

Temporary phases of caloric restriction (CR) are typically used to reduce body mass (Gardner et al. 2018; Schwartz et al. 2017). Although, in most cases, the goal of these interventions is to reduce fat mass, lean tissue loss is often concomitantly observed as a negative side effect during prolonged CR (Ryan and Nicklas 2004; Bouchard et al. 2009;

Communicated by Michael I Lindinger.

C. Roth

roth@sport.uni-frankfurt.de

1 Department of Sports Medicine and Exercise Physiology, Institute of Sport Sciences, Goethe University Frankfurt, Ginnheimer Landstrasse 39, 60487 Frankfurt/Main, Germany

2 Department of Health Sciences, CUNY Lehman College, Bronx, NY, USA
Karila et al. 2008). Weinheimer et al. (2010) concluded that, on average, $24 \%$ (dietary-only) and $11 \%$ (diet $\times$ exercise) of CR-induced weight loss are attributed to a reduction of lean tissue. Unfortunately, lean mass loss brings about additional negative consequences such as a decreased resting metabolic rate (Stiegler and Cunliffe 2006), which in turn increases the likelihood for the regain of body mass, mainly in the form of increased body fat (Maclean et al. 2011). It is therefore important to devise strategies that spare lean mass during prolonged CR interventions, which may also be of benefit to athletes who compete in sports involving body aesthetics or weight categories (e.g., bodybuilders, wrestlers, boxers, etc.). This objective, commonly referred to as high-quality weight loss, aims to reduce body fat while maintaining as much lean tissue as possible (Churchward-Venne et al. 2013).

Lean mass sparing is determined by the dynamic balance between muscle protein synthesis (MPS) and proteolysis (Biolo et al. 1995; Phillips et al. 1997). In this regard, 
CR leads to reduced responses to anabolic and anti-catabolic stimuli when compared to eucaloric conditions (e.g., leucine-induced effects on cell signaling and MPS; Gwin et al. 2020a; Pasiakos et al. 2010, 2014), potentially affects activation of proteolytic pathways via reduced insulin levels (Greenhaff et al. 2008; Tipton et al. 2018), and culminates in an increased likelihood of lean mass loss. Moreover, the rate of MPS declines as an adaptive mechanism to conserve energy, which conceivably serves as a primary reason for lean tissue loss during hypocaloric conditions (Carbone et al. 2012; Margolis et al. 2016; Miller et al. 2012). Optimal approaches for lean mass sparing during CR should therefore focus on counteracting the decline in MPS by modifying dietary and mechanical [i.e., resistance training (RT)] stimuli (Weinheimer et al. 2010; Cava et al. 2017; Carbone et al. 2019).

It is well known that a high-protein diet contributes to an elevation of mixed MPS (Pasiakos et al. 2013) and whole-body protein synthesis (Gwin et al. 2020a) as well as helping to inhibit insulin-sensitive protein breakdown (insulin-IGF-1-PI3K), which therefore partially counteracts the negative consequences of prolonged CR (Jäger et al. 2017; Hudson et al. 2020; Gwin et al. 2020b). In addition, mechanical loading, such as in RT, interacts synergistically with a high-protein diet to further elevate MPS (Phillips et al. 1997; Churchward-Venne et al. 2012). Even during $\mathrm{CR}$, this combination has been shown to preserve lean mass in obese individuals (Rice et al. 1999; Longland et al. 2016) and elite-level athletes (Garthe et al. 2011). However, these findings cannot be extrapolated to resistance-trained individuals due to divergent intracellular (Moberg et al. 2020) and MPS responses (Tang et al. 2008; Damas et al. 2015), as well as blood metabolome differences (Schranner et al. 2021) between populations. To this point, a lean tissue loss of $\sim 43 \%$ of the lost body mass was reported for a resistancetrained athlete undergoing CR, despite implementation of a high-protein diet and regimented RT (Kistler et al. 2014).

It is currently unknown if and how RT variables need to be adjusted to spare lean mass in resistance-trained athletes. Although different RT variables elicit different intracellular signaling responses and, thus, morphological adaptations (Toigo and Boutellier 2006), RT volume, in total tonnage [number of repetitions $\times$ number of sets $\times$ intensity load; $\mathrm{kg}$ ] or simply counted as sets per muscle group per week (Baz-Valle et al. 2018; Israetel et al. 2019), might play an important role in muscular adaptations (Figueiredo et al. 2018): While several authors suggest an inverted $U$-shaped relationship between weekly volume and hypertrophy during eu- and hypercaloric conditions (Schoenfeld et al. 2019, 2017b) with higher RT volumes (up to a certain threshold) being necessary for advanced athletes to maximize hypertrophy (ACSM 2009; Krzysztofik et al. 2019), preliminary data suggest a potential positive effect of higher volume RT on lean mass sparing during periods of CR (Dudgeon et al. 2017; Mitchell et al. 2018). Contrarily, some investigators report reduced RT volume during phases of high-energy demands to accommodate recovery ability (Chaouachi et al. 2009; Meckel et al. 2008; Vargas-Molina et al. 2020; Campbell et al. 2020). Since RT volume is a well-known anabolic stimulus for muscle hypertrophy (Schoenfeld et al. 2017b), this review investigates whether higher training volumes are more appropriate for sparing lean mass during CR.

\section{Methods}

\section{Inclusion criteria}

The review focused on studies published in English and German language peer-reviewed journals. To meet inclusion criteria, the study had to: (1) include lean, healthy, drug-free resistance-trained individuals, (2) last at least 4 weeks, (3) investigate hypocaloric conditions ( $\geq 200 \mathrm{kcal}$ deficit/day), (4) report pre-post data for changes in lean mass, (5) employ a high-protein diet $\geq 2.0 \mathrm{~g} / \mathrm{kg}$ fatfree mass (FFM), and (6) present information about RT variables used.

\section{Search strategy}

A systematic literature search was performed using the PubMed, MEDLINE, and SPORTDiscus databases between 1990 and December 2020 according to the Preferred Reporting Items for Systematic Reviews and Meta-Analyses (PRISMA) guidelines (Moher et al. 2009). Searches were performed using the following keywords: 'resistancetrained', 'bodybuilder', 'bodybuilding', 'recreationally active', 'contest preparation', 'competition', 'exercise', 'strength training', 'lean mass', 'retention', 'volume', 'athlete', 'weight loss', 'energy restriction', 'energy deficit', 'caloric restriction', 'body composition', 'hypocaloric diet', 'ketogenic', 'time-restricted feeding', as well as combinations of these. In addition, author names and reference lists were used for further search (Greenhalgh and Peacock 2005).

Our analysis includes initial and final body fat mass levels, protein consumption, study duration, estimated caloric deficit, RT protocol with special emphasis on RT volume used (total tonnage, sets/muscle group per week or sets/exercise), absolute and relative lean mass loss, and assessment technique. These factors were selected given their proposed role in lean tissue sparing during CR (Heymsfield et al. 2011). 


\section{Coding of studies and methodological quality}

The potentially relevant studies were perused and coded for the following criteria as per Schoenfeld et al. (2017a): (1) authors, title, and year of publication; (2) participant information, such as sample size, sex, age, and training experience. When possible, participants were categorized regarding the bodybuilding class in which they competed; in absence of this information, participants were classified based on RT experience (years of training); (3) description of the training intervention, including repetition ranges, weekly training frequency, exercises and RT volume used, with multi-joint exercises coded for the muscle group that is predominantly trained. RT volume was preferentially expressed in total tonnage (number of repetitions $\times$ number of sets $\times$ intensity load; $\mathrm{kg}$ ) or, when not applicable, in weekly sets/muscle group. In the event that information regarding RT variables was missing, we quantified RT volume as sets/exercise. As suggested by Schoenfeld et al. (2017b), total sets per muscle group per week were categorized as follows: low $(<5)$, medium $(5-9)$, or high $(10+)$; (4) methods of measurement were categorized as direct (magnetic resonance imaging, computerized tomography, and ultrasound) and indirect \{ underwater weighing (UWW), dual-energy X-ray absorptiometry (DXA), air displacement plethysmography (ADP), and bioelectrical impedance analysis (BIA) \}. When direct measures were employed, we noted the specific muscle group assessed.

\section{PEDro scale}

The PEDro scale (Maher et al. 2003) was selected to assess the methodological quality of the studies (Table 1). Consistent with previous exercise-related reviews (Schoenfeld and
Grgic 2020), the first item of the scale (referring to external validity) was not taken into account for the final score as recommended in the guidelines. Furthermore, items 5, 6, and 7 were excluded as well due to the difficulty of blinding in exercise-related interventions. Thus, the maximum result was seven, categorized as follows (Schoenfeld and Grgic 2020): 6-7="excellent quality"; 5 = "good quality"; $4=$ "moderate quality"; $0-3=$ " "poor quality", in line with other reviews (Kümmel et al. 2016).

\section{Results}

A total of 2791 studies were identified based on the search criteria. With respect to the studies' abstracts, 51 of the reviewed studies were chosen to be potentially relevant for data analysis. The full texts of these articles were then screened; 36 of these studies (Greene et al. 2018; Helms et al. 2015b; Mero et al. 2010; Newton et al. 1993; Sawyer et al. 2013; Tinsley et al. 2017; Trabelsi et al. 2013, 2012; Vargas et al. 2018; Walberg-Rankin et al. 1993; Waldman et al. 2018; Kleiner et al. 1990; Bamman et al. 1993; Hickson et al. 1990; Withers et al. 1997; Wilson et al. 2017; Chatterton et al. 2017; Durguerian et al. 2016; Murphy and Koehler 2020; Gentil et al. 2017; Steen 1991; Manore et al. 1993; Too et al. 1998; Moro et al. 2016; Areta et al. 2014; Kysel et al. 2020; Philpott et al. 2019; Huovinen et al. 2015; Antonio et al. 2019; Bazyler et al. 2018; Mäestu et al. 2008, 2010; Dudgeon et al. 2016; Mettler et al. 2010; Rossow et al. 2013; Syed-Abdul et al. 2019) were excluded from analysis for various reasons. Thus, 15 studies were used for qualitative analysis. Figure 1 shows a flowchart of the literature search strategy; Table 2 summarizes the studies included for analysis.
Table 1 PEDro scale (Maher et al. 2003)

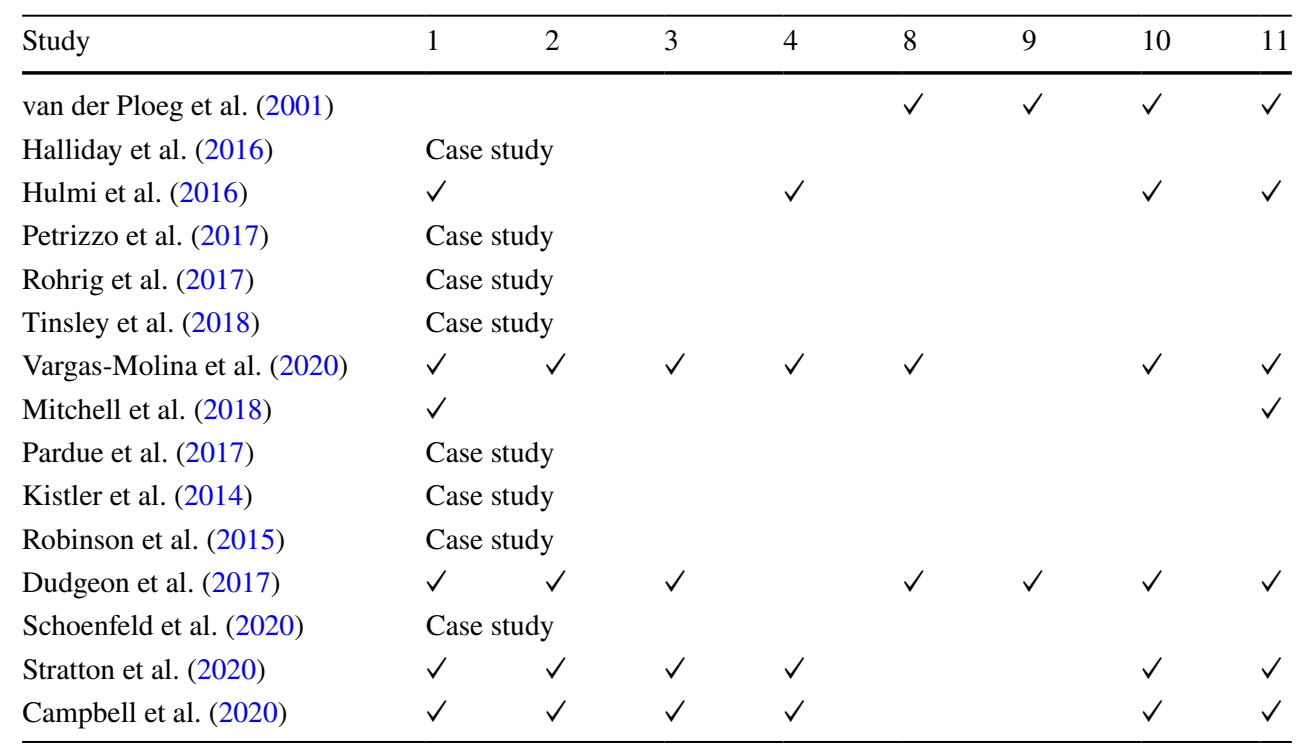




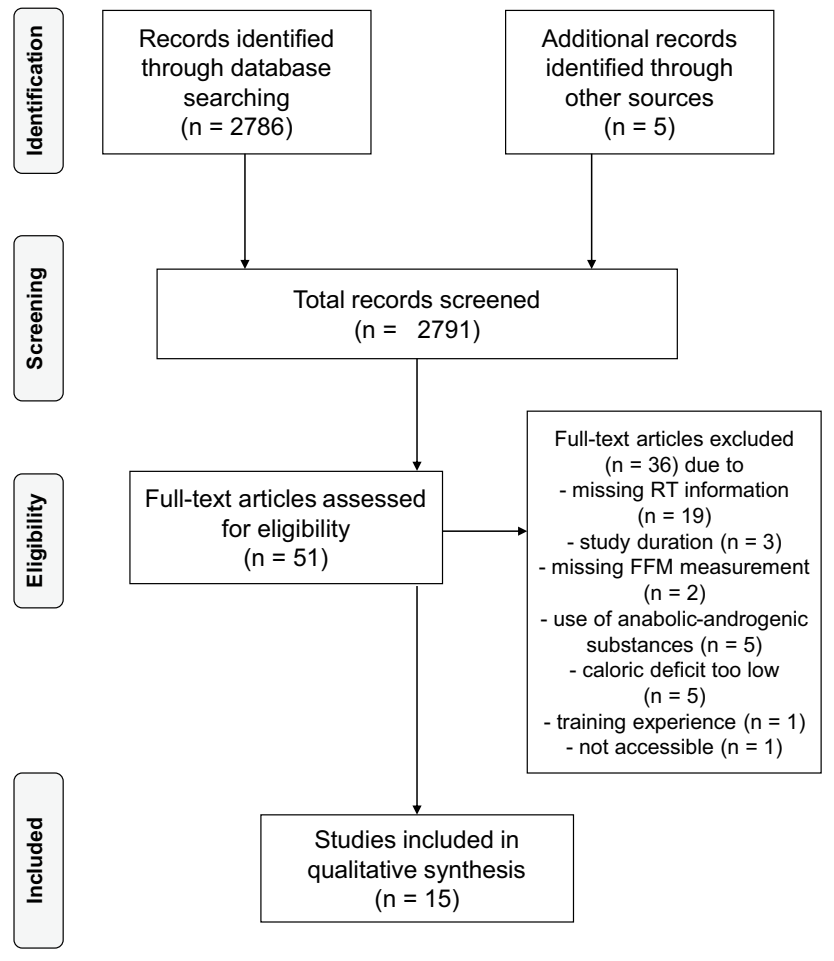

Fig. 1 PRISMA flowchart

\section{Sex distribution, study design, and intervention period}

Seven studies recruited female participants. Of these 7 studies, 3 employed a longitudinal design (van der Ploeg et al. 2001; Hulmi et al. 2016; Vargas-Molina et al. 2020), while the remaining 4 were case studies (Halliday et al. 2016; Petrizzo et al. 2017; Rohrig et al. 2017; Tinsley et al. 2018). Seven studies recruited male participants. Out of these 7 studies, 3 studies employed a longitudinal design (Dudgeon et al. 2017; Stratton et al. 2020), with one study providing no control group (Mitchell et al. 2018): the other 4 studies were case studies (Pardue et al. 2017; Kistler et al. 2014; Robinson et al. 2015; Schoenfeld et al. 2020). One study (Campbell et al. 2020) used mixed-sex groups. The average study duration was 18.19 weeks ( $M d n=18$ weeks) and ranged between 4 weeks (Stratton et al. 2020) and 8 months (Schoenfeld et al. 2020; Pardue et al. 2017).

\section{Participants' characteristics}

The studies finally encompassed a total of 129 participants, consisting of 60 female and 69 male participants. Across the studies, 48 participants withdrew, with 5 studies reporting the reasons for withdrawal (Campbell et al. 2020; Mitchell et al. 2018; Stratton et al. 2020; Hulmi et al. 2016; Vargas-Molina et al. 2020). A majority of studies employed resistance-trained athletes except for Stratton et al. (2020), who characterized participants as recreationally trained. On average, mean training experience equated to 6.02 years $(\mathrm{Mdn}=5.5$ years $)$ and ranged between "at least 6 months" (Stratton et al. 2020) to 10 years (Schoenfeld et al. 2020; Kistler et al. 2014). Mean age was 25.9 years ranging from 21 (Pardue et al. 2017; Robinson et al. 2015) to 35.3 years (van der Ploeg et al. 2001). Initial body fat averaged $21.7 \%$ [ranging from $14.6 \%$ (Hulmi et al. 2016) to 30.5\% (Rohrig et al. 2017)] and $14.9 \%$ [ranging from $9.5 \%$ (Schoenfeld et al. 2020) to $19.9 \%$ (Stratton et al. 2020)] in females and males, respectively; $\Delta$ body fat loss averaged $-7.9 \%$ in females and $-5.2 \%$ in males in total.

\section{Estimated caloric deficit, diet differences, and protein consumption}

Based on the amount of weight lost, the estimated energy deficit per day ranged between $-250 \mathrm{kcal}$ (Halliday et al. 2016) and $-882 \mathrm{kcal}$ per day (Robinson et al. 2015) with a mean deficit of $-347 \mathrm{kcal}$ and $-398 \mathrm{kcal}$ per day in females and males, respectively. Most of the studies reported a gradual decrease in energy intake during the trials. One study (Campbell et al. 2020) employed an intermittent dieting protocol $[5$ days dieting $(-35 \%$ reduction from maintenance caloric needs) followed by a 2-day diet break (consumption at maintenance caloric needs) and included a continuous dieting group as controls $(-25 \%)$ ]. While most of the studies were carried out using a low-fat diet, 3 studies employed a carbohydrate-cycling protocol (Halliday et al. 2016; Kistler et al. 2014; Pardue et al. 2017) and 1 study used a ketogenic diet protocol (Vargas-Molina et al. 2020). Mean protein consumption was $3.35 \mathrm{~g} / \mathrm{kg}$ FFM in females and $3.06 \mathrm{~g} / \mathrm{kg}$ FFM in males, and ranged between $2.12 \mathrm{~g} / \mathrm{kg}$ FFM (Campbell et al. 2020) and $4.00 \mathrm{~g} / \mathrm{kg}$ FFM (Petrizzo et al. 2017).

\section{Exercise protocols, volume quantification, lean mass change, and assessment techniques}

Eleven out of 15 studies used concurrent aerobic training (high-intensity interval, moderate-intensity, or low-intensity steady-state training), which was typically (van der Ploeg et al. 2001; Petrizzo et al. 2017; Rohrig et al. 2017; Tinsley et al. 2018; Kistler et al. 2014; Robinson et al. 2015; Hulmi et al. 2016; Pardue et al. 2017), but not always (Campbell et al. 2020; Halliday et al. 2016; Schoenfeld et al. 2020), increased to support gradual weight loss. RT per week varied between 2 and 7 days. Most studies employed 2 RT sessions per muscle group; however, this ranged between 1 (Dudgeon et al. 2017) and 7 (Schoenfeld et al. 2020) days per week. Repetitions ranged from 3 to 30 across trials with 3 studies employing RT to concentric failure (Petrizzo et al. 2017; Tinsley et al. 2018; Vargas-Molina et al. 2020) and 


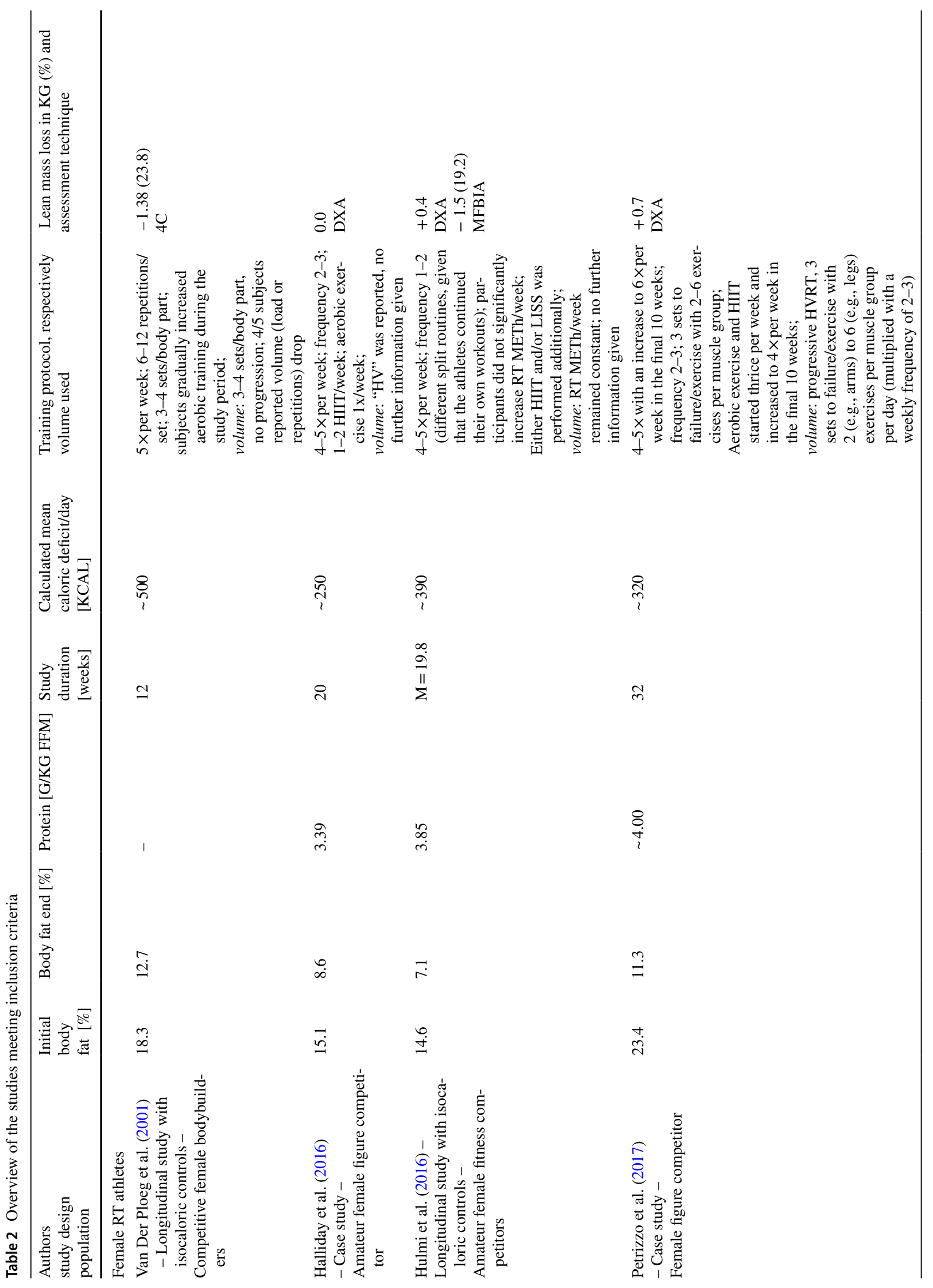




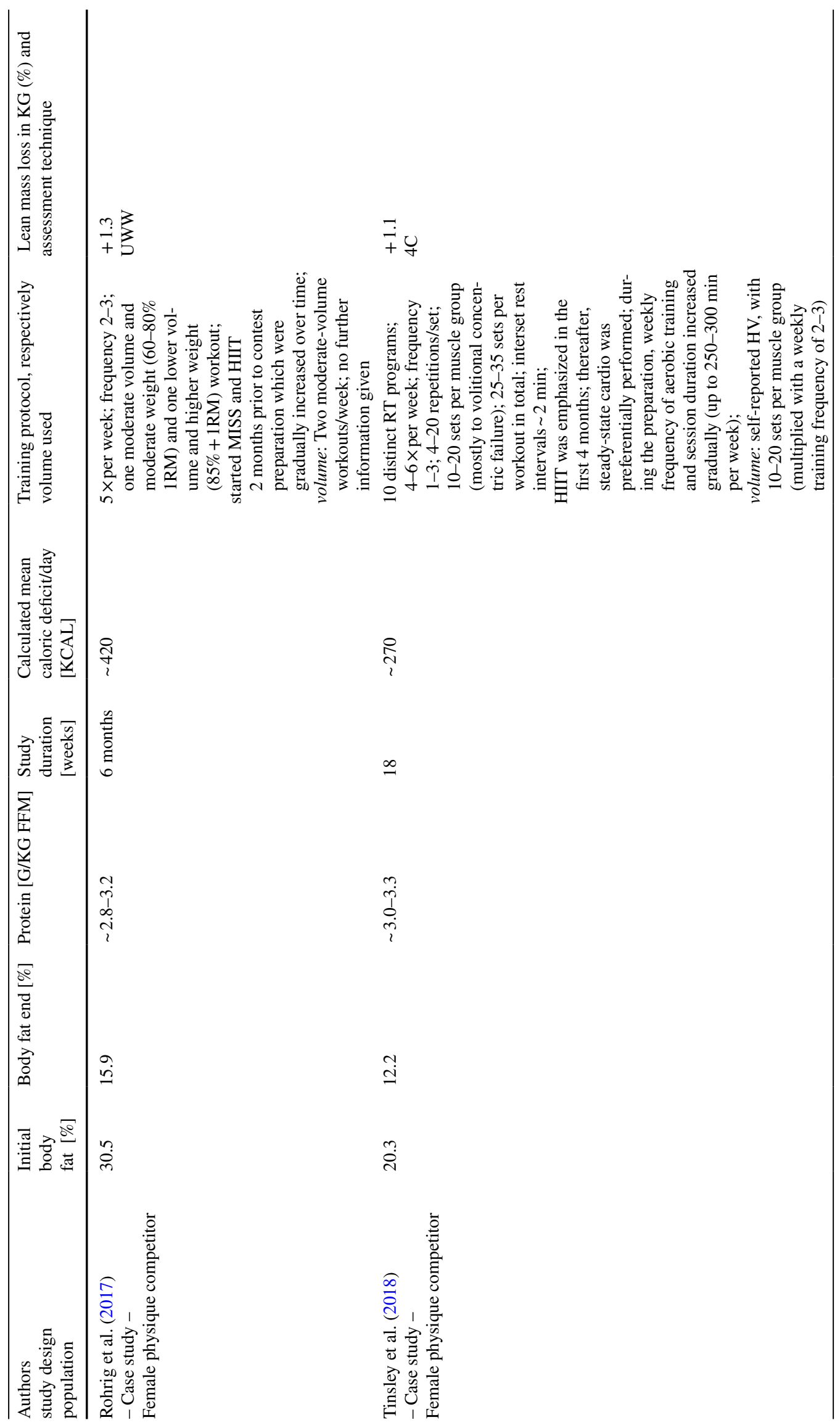




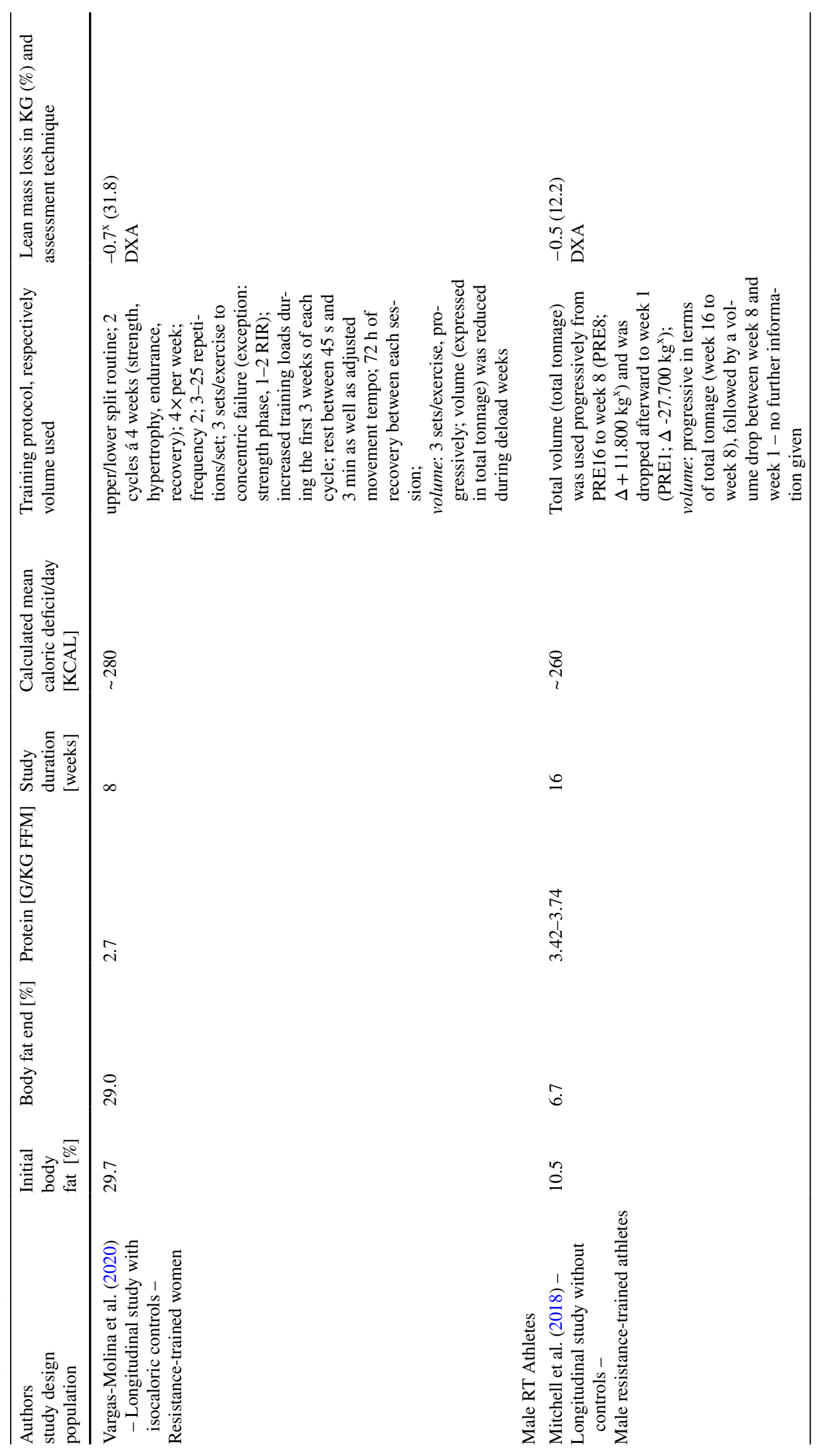




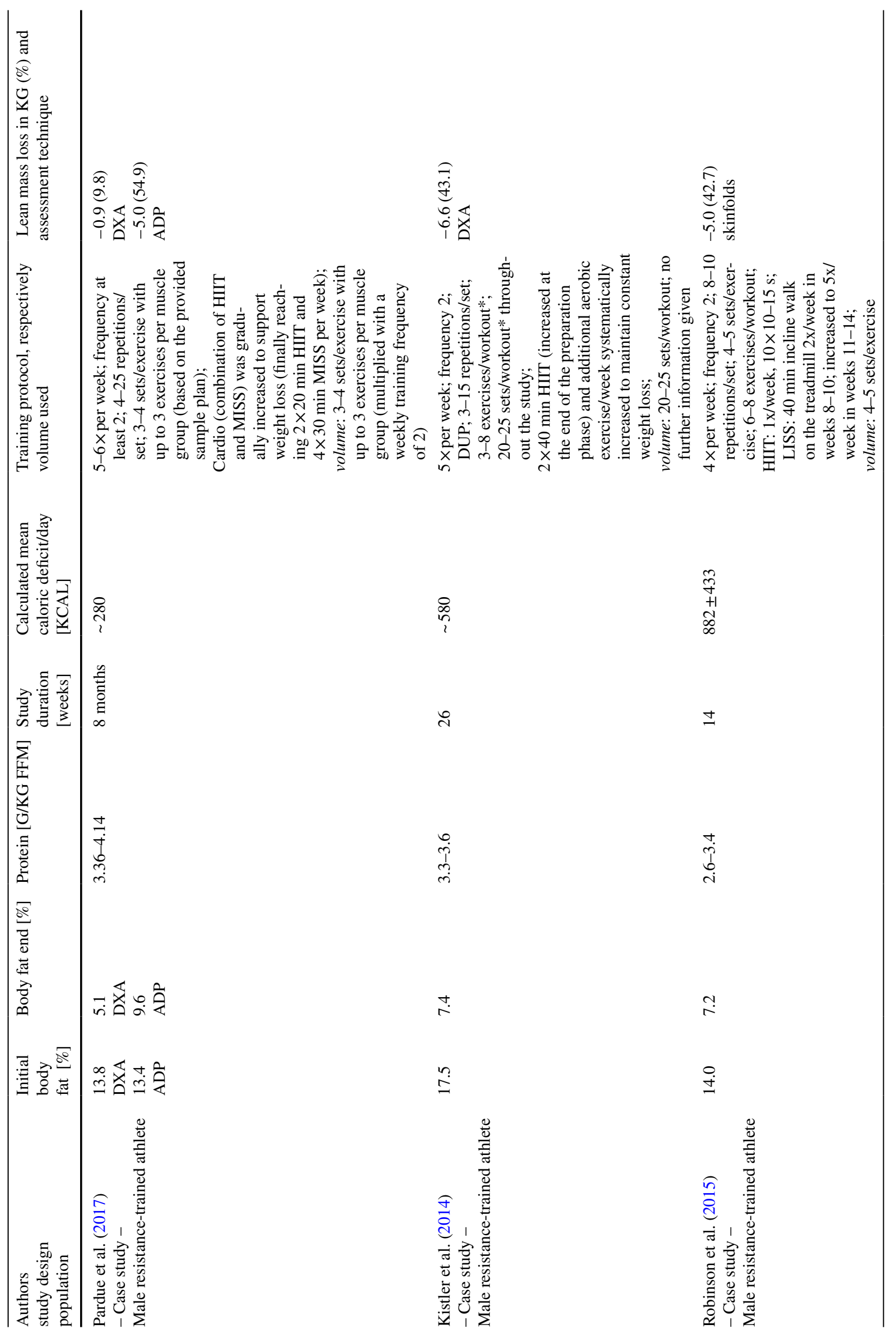




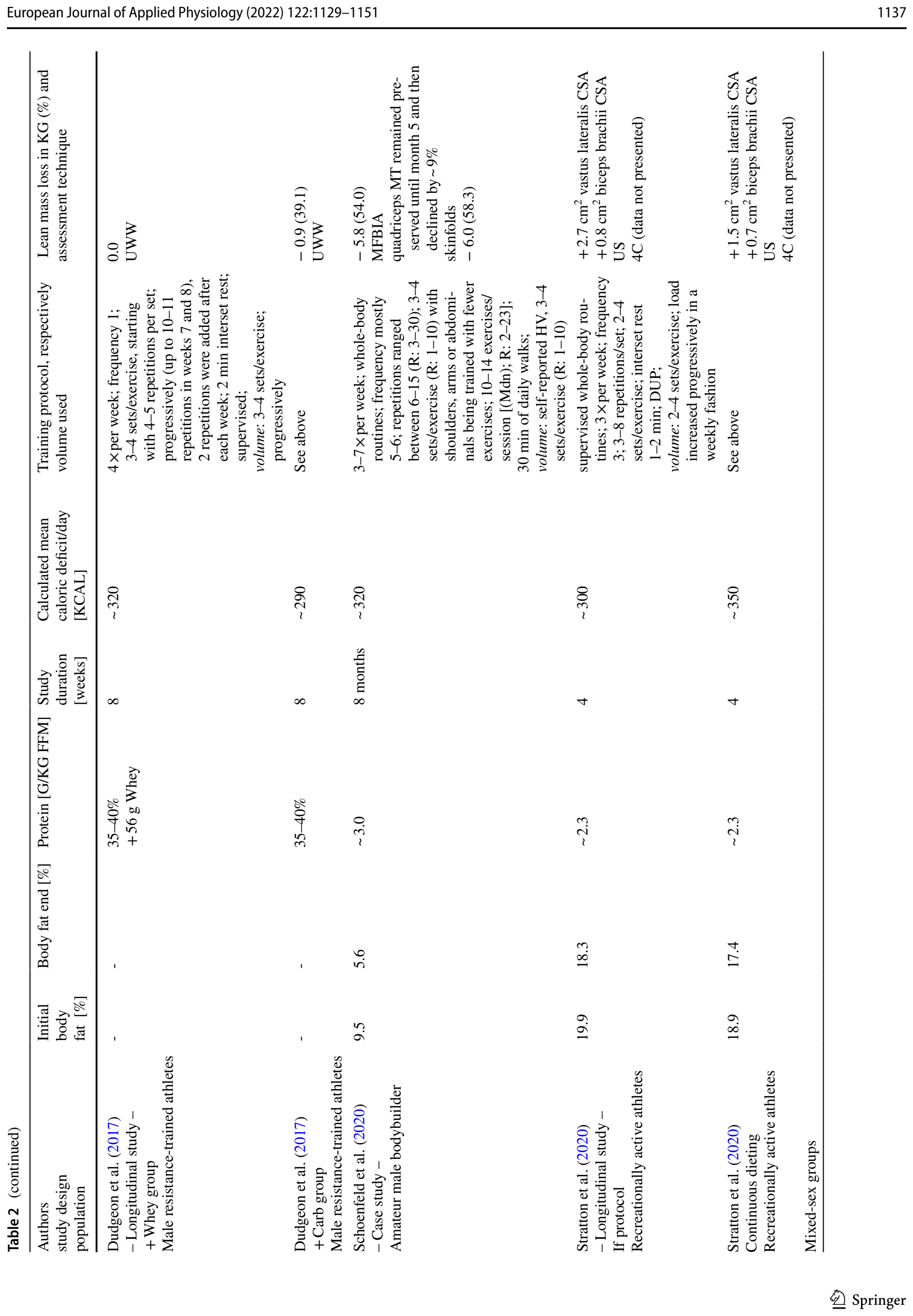




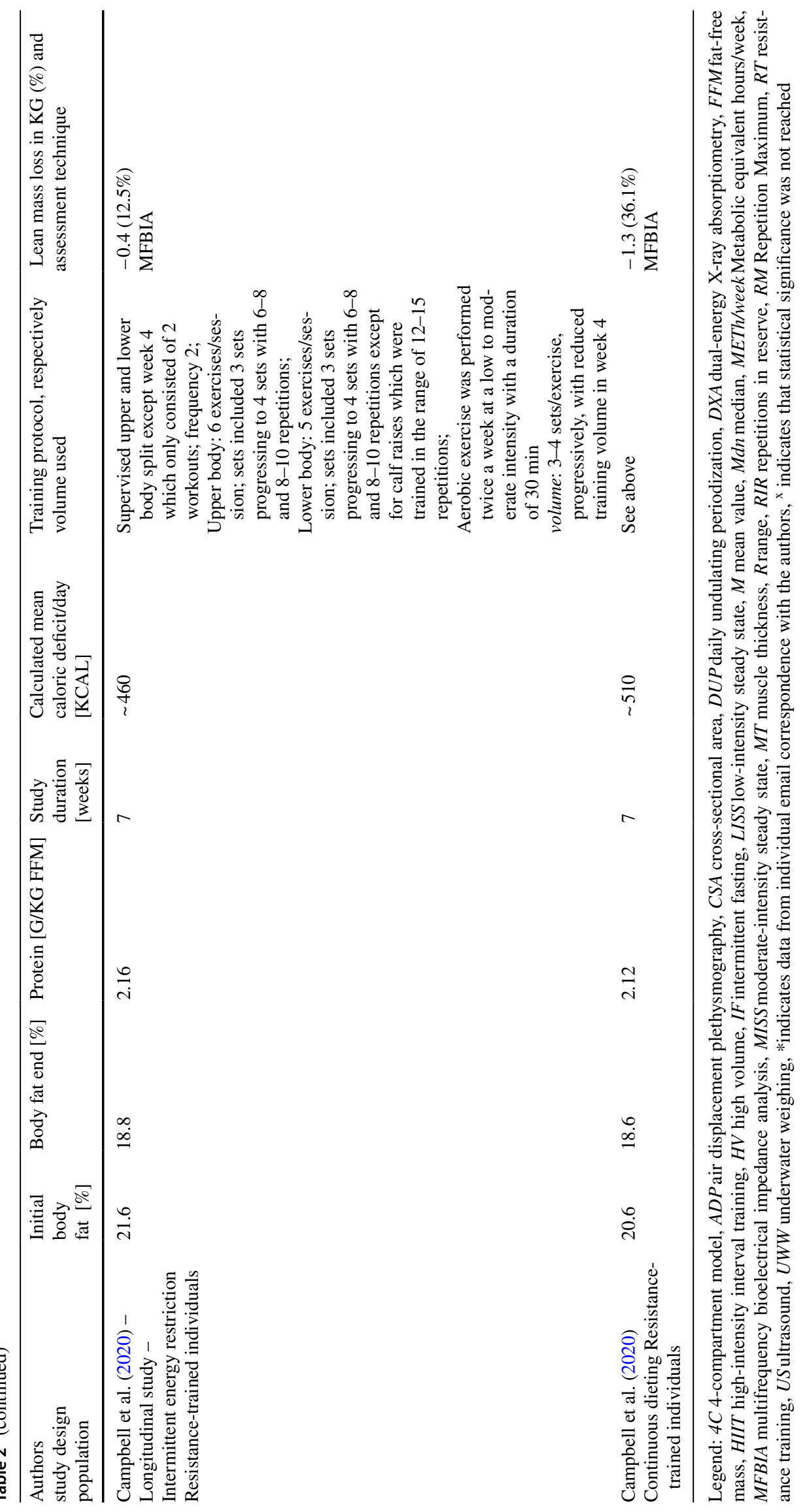


3 studies reporting daily undulating periodized loading schemes (Kistler et al. 2014; Stratton et al. 2020; Rohrig et al. 2017). Interset rest intervals ranged between $45 \mathrm{~s}$ and $3 \mathrm{~min}$, but were only reported in 4 studies (Tinsley et al. 2018; Vargas-Molina et al. 2020; Dudgeon et al. 2017; Stratton et al. 2020).

Only one of the included studies (Mitchell et al. 2018) provided volume quantification in total tonnage lifted (repetitions $\times$ sets $\times$ intensity load). Weekly sets per muscle group were reported in 3 studies (Petrizzo et al. 2017; Tinsley et al. 2018; Pardue et al. 2017). Volume configurations were highly dependent on the examined muscle group, as well as on the number of weekly training sessions for the same muscle group. Overall, volume ranged from 10 sets per muscle group per week (e.g., arms; Petrizzo et al. 2017; Tinsley et al. 2018) to $>20$ (Pardue et al. 2017) and $>30$ sets/muscle group per week (mostly legs; Petrizzo et al. 2017). In the remaining studies, volume was either depicted as sets/exercise (van der Ploeg et al. 2001; Vargas-Molina et al. 2020; Robinson et al. 2015; Dudgeon et al. 2017; Schoenfeld et al. 2020; Stratton et al. 2020; Campbell et al. 2020), ranging between 1 and 10 sets/exercise, or could not be calculated adequately (Halliday et al. 2016; Hulmi et al. 2016; Rohrig et al. 2017; Kistler et al. 2014). Notably, 1 study (Halliday et al. 2016) referenced their RT protocol as high-volume without providing any information about RT volume. Finally, 3 of the 15 studies were carried out under direct supervision (Campbell et al. 2020; Dudgeon et al. 2017; Stratton et al. 2020).

Five studies increased RT volume over time either via sets/exercise or by increasing the weight lifted (Petrizzo et al. 2017; Vargas-Molina et al. 2020; Dudgeon et al. 2017; Stratton et al. 2020; Campbell et al. 2020), with 1 study mentioning RT changes in METh/week (Hulmi et al. 2016). Three studies reduced RT volume (van der Ploeg et al. 2001; Vargas-Molina et al. 2020; Campbell et al. 2020), whereas 1 study reported an increase followed by a decrease in total tonnage lifted during the course of bodybuilding contest preparation (Mitchell et al. 2018).

In general, average body mass loss was $-4.8 \mathrm{~kg}$ and $-5.0 \mathrm{~kg}$ in females and males, respectively. Lean mass changes varied between $+1.3 \mathrm{~kg}$ and $-6.6 \mathrm{~kg}$, with a relative lean tissue loss up to approximately $54 \%$ of the total loss in body mass (Schoenfeld et al. 2020). When divided by sex, 2 of 7 studies in females and 5 of 7 studies in males reported lean tissue loss during dieting, suggesting a significant influence of sex on lean tissue change during CR. On average, females gained $0.2 \mathrm{~kg}$ lean tissue during dieting with 1 study (Hulmi et al. 2016) reporting contradictory results between DXA and multifrequency BIA. Except for 2 studies (van der Ploeg et al. 2001; Vargas-Molina et al. 2020), the studies using female participants reported muscle mass maintenance (Halliday et al. 2016) or even an increase in lean tissue (+1.03 kg on average) (Petrizzo et al. 2017; Rohrig et al. 2017; Tinsley et al. 2018). Except for Rohrig et al. (2017), who reported moderate volume workouts, the latter mentioned studies labeled themselves as high-volume or increased RT volume over time (CR ranging from $-270 \mathrm{kcal} /$ day to $-320 \mathrm{kcal} /$ day) and can be categorized as high-volume according to our a priori classification criteria. Contrarily, studies reporting decreased RT volume (Vargas-Molina et al. 2020; van der Ploeg et al. 2001) observed lean tissue losses $(-1.04 \mathrm{~kg}$ on average; CR ranging from $-280 \mathrm{kcal} /$ day to $-500 \mathrm{kcal} / \mathrm{day})$. The time course of absolute lean tissue changes for men and women is presented in Fig. 2.

On average, the lean tissue loss was $-2.81 \mathrm{~kg}$ in males $(\mathrm{Mdn}=-0.9 \mathrm{~kg}$ ) with a relative mean loss of $28.7 \%$ of the loss in total body mass $(\mathrm{Mdn}=39.1 \%)$. While absolute lean mass loss ranged from $-0.5 \mathrm{~kg}$ to $-6.6 \mathrm{~kg}$, relative losses ranged between $12 \%$ and $54 \%$ of the weight lost, with 1 study (Pardue et al. 2017) reporting contradictory results between DXA and ADP. Except for 1 study that reported no lean tissue loss in the + WHEY intervention group (Dudgeon et al. 2017) and another study reporting increases in crosssectional area (CSA) (Stratton et al. 2020), the remaining 5 studies observed lean tissue losses (Robinson et al. 2015; Schoenfeld et al. 2020; Kistler et al. 2014; Pardue et al. 2017; Mitchell et al. 2018). When evaluating the relationship between lean tissue changes and RT volume, studies that reported no loss (Dudgeon et al. 2017; Stratton et al. 2020) or even an increase in lean mass after 8 weeks of CR (Mitchell et al. 2018), all increased RT volume over time (CR ranging from $-260 \mathrm{kcal} / \mathrm{day}$ to $-350 \mathrm{kcal} /$ day). Contrarily, when RT volume was reduced, a loss of lean mass was reported (Mitchell et al. 2018). Overall, most of the studies assessed body composition via DXA (Kistler et al. 2014; Halliday et al. 2016; Hulmi et al. 2016; Petrizzo et al. 2017; VargasMolina et al. 2020; Mitchell et al. 2018; Pardue et al. 2017), followed by multifrequency BIA (Hulmi et al. 2016; Schoenfeld et al. 2020; Campbell et al. 2020), skinfold measures (Hulmi et al. 2016; Robinson et al. 2015; Schoenfeld et al. 2020), 4C models (van der Ploeg et al. 2001; Tinsley et al. 2018), UWW (Rohrig et al. 2017; Dudgeon et al. 2017), and ADP (Pardue et al. 2017). Three studies used ultrasound as a direct measure (Hulmi et al. 2016; Schoenfeld et al. 2020; Stratton et al. 2020).

\section{Discussion}

The purpose of this review was to assess whether higher RT volumes help to spare lean mass during CR. Volume configurations were highly dependent on the examined muscle group as well as on the number of weekly training sessions for the same muscle group. According to the volume classification used in this review, 3 studies could be categorized as 

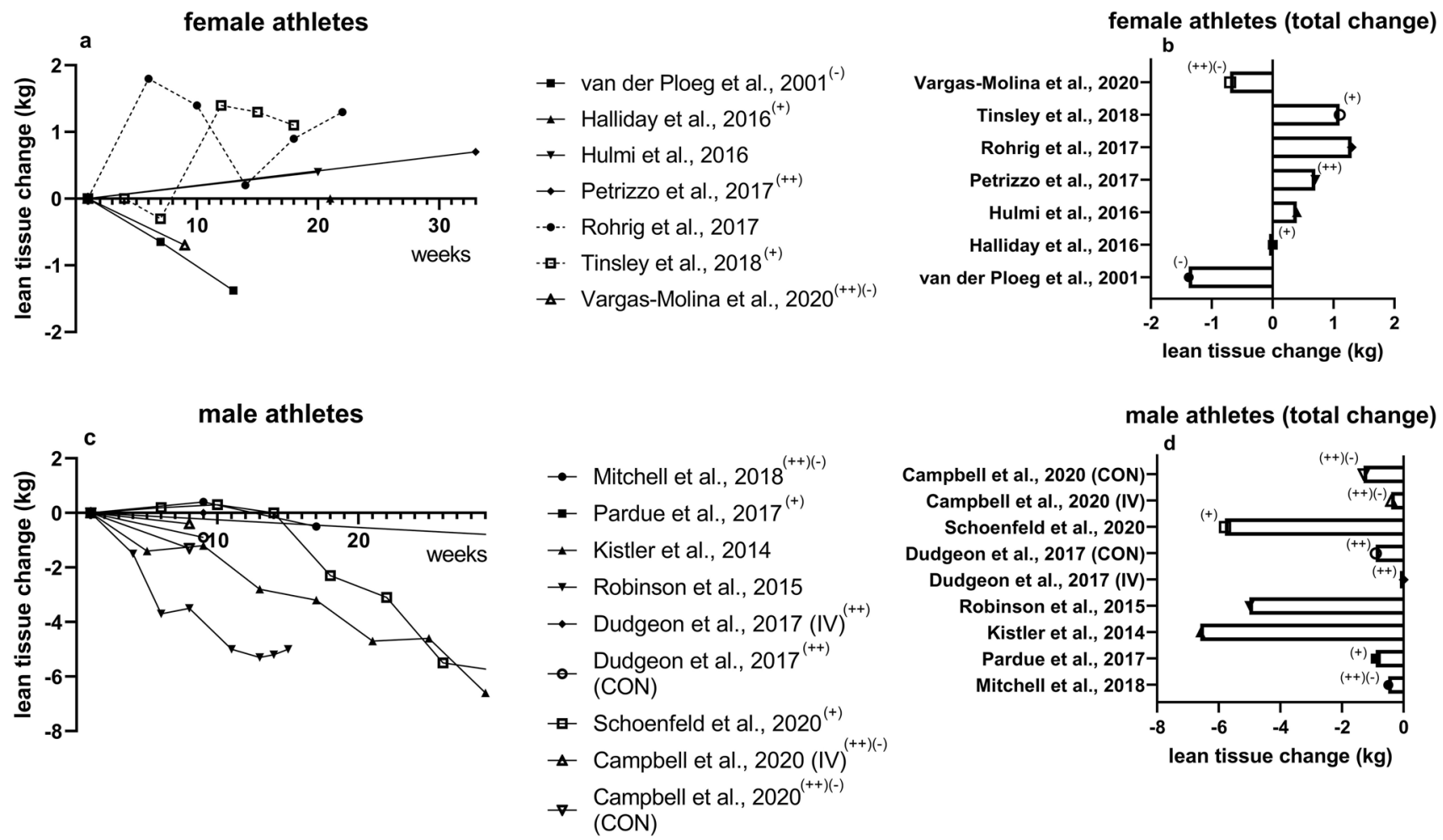

Fig. 2 Time course of lean tissue changes during CR in kilograms. Longitudinal depiction of (a) female and (c) male athletes as well as absolute visualization of (b) female and (d) male athletes. $(+)$ indicates (self-reported) high-volume RT; $(++)$ indicates progressive

high-volume, ranging from 10 to $>30$ weekly sets per muscle group, which revealed low-to-no (mostly female) lean mass loss. Volume quantification in total tonnage was only provided by 1 study (Mitchell et al. 2018), with the authors reporting an increase in lean mass after increasing the total tonnage lifted (repetitions $\times$ sets $\times$ intensity load). Unfortunately, the provided data allowed calculation of total tonnage lifted or weekly sets per muscle group for only 4 of the 15 studies. Therefore, due to incomplete data regarding RT variables applied, there is insufficient evidence to conclude that a higher RT volume is advantageous for sparing lean mass during $\mathrm{CR}$, although the data do seem to favor highvolume RT in female athletes under these circumstances. Longitudinal studies using male participants under CR are less conclusive, with 1 study reporting high lean mass loss despite being referenced as high-volume by the authors (Schoenfeld et al. 2020). Moreover, the data appear to suggest that progressively increasing RT volume over time during CR may be more effective in ameliorating CR-induced atrophy in both female and male resistance-trained athletes as opposed to reducing RT volume. Our conclusion appears to be supported by endocrine (Schoenfeld et al. 2020; Stratton et al. 2020; Rossetti et al. 2017) and intracellular findings (Areta et al. 2014; Pasiakos et al. 2013; Hornberger 2011), overload over time, (-) indicates reduced volume; without symbols means that volume tendency could not be specified; Stratton et al. 2020 was not included due to missing whole-body lean mass data. $C O N$ control group, $I V$ intervention group

underpinning potential explanations for increased lean mass sparing. Our findings also indicate that, on average, women tend to spare more lean mass than men during CR.

\section{Female resistance-trained athletes}

Seven CR studies with female participants met our inclusion criteria (Halliday et al. 2016; Hulmi et al. 2016; Petrizzo et al. 2017; Rohrig et al. 2017; Tinsley et al. 2018; van der Ploeg et al. 2001; Vargas-Molina et al. 2020). Except for three studies (van der Ploeg et al. 2001; Hulmi et al. 2016; Vargas-Molina et al. 2020), the remaining studies reported muscle mass maintenance (Halliday et al. 2016) or an increase in lean mass (Petrizzo et al. 2017; Rohrig et al. 2017; Tinsley et al. 2018). When evaluating the relationship between lean tissue changes and RT volume, the latter mentioned studies either self-reported their volume as moderate without providing set numbers (Rohrig et al. 2017), increased RT volume over time (Petrizzo et al. 2017), or met our established criteria as a high-volume protocol (Petrizzo et al. 2017; Tinsley et al. 2018). Conversely, studies reporting decreased RT volume (van der Ploeg et al. 2001; VargasMolina et al. 2020) tended to observe lean tissue loss. 
For instance, van der Ploeg et al. (2001) reported that participants lost $-1.38 \mathrm{~kg}$ lean mass on average $(23.8 \%$ of the lost mass). Although the study did not report protein intake, volume (in terms of load or repetitions) was reduced by $4 / 5$ participants during the study. Since the remaining studies did not report any changes in the RT protocol (Halliday et al. 2016; Rohrig et al. 2017), increased volume (Petrizzo et al. 2017), or steadily changed RT programing to induce novel stimuli (Tinsley et al. 2018), it is plausible that the reduced volume contributed to the lean mass loss. This is in accordance with other research reporting a similar lean mass loss and decreased volume in 2 of 8 weeks (Vargas-Molina et al. 2020).

Except for one study (Halliday et al. 2016) that reported lean mass maintenance, the remaining studies (Petrizzo et al. 2017; Rohrig et al. 2017; Tinsley et al. 2018) found that female athletes gained lean mass during CR. Unfortunately, Rohrig et al. (2017) only reported information on two moderate-volume and two high-intensity workouts without providing further details (lean mass gain $+1.3 \mathrm{~kg}$ ), thus precluding in depth analysis. Other studies provided more detailed information about exercise and nutritional variables (Petrizzo et al. 2017; Tinsley et al. 2018): For instance, Petrizzo et al. (2017) stated that their participant ingested $\sim 4.00 \mathrm{~g} / \mathrm{kg}$ FFM protein/day on average and completed high-volume RT during the course of the study (lean mass gain $+0.7 \mathrm{~kg}$ ). Contest preparation started with RT performed $4-5 \times$ per week and progressively increased to 6x/week, while RT volume per session remained the same. In every workout, the athlete trained with 2-6 exercises per muscle group with 3 sets to momentary muscle failure per exercise. Although it is unclear whether RT volume was increased over time in the study by Tinsley et al. (2018), the high-volume RT protocol (4-6 times/week on average with 10-20 sets per muscle group) led to a significant increase in lean mass $(+1.1 \mathrm{~kg})$. It is noteworthy that the majority of studies employed protein intakes at the upper limits of what is recommended for weight loss phases (Roberts et al. 2020; Helms et al. 2014). Since a high-protein intake appears to attenuate stress and fatigue compared to a moderate-protein intake during CR (Helms et al. 2015b), it is plausible that the markedly high-protein intake seen in this review might have allowed a non-perturbed RT performance, potentially helping to indirectly spare lean mass. More research is warranted to elucidate the interaction between protein intake and RT performance (e.g., referring to volume tolerance, strength change, stress, and fatigue accumulation) during $\mathrm{CR}$.

Although preliminary evidence seems to suggest that high-volume RT leads to an increase in lean mass during CR in resistance-trained female athletes (Petrizzo et al. 2017; Tinsley et al. 2018), incomplete data hamper the strength of relationship between variables. However, since studies that cut back RT volume reported atrophic effects, increasing volume over time during $\mathrm{CR}$ appears to be a promising approach to achieve high-quality weight loss in female athletes. This is in line with the proposed inverted U-shaped relationship of hypertrophy during eucaloric conditions, with RT volume appearing to elicit anabolism in a dosedependent fashion (Schoenfeld et al. 2017b; Figueiredo et al. 2018), and leads us to speculate that similar anabolic effects may occur during $\mathrm{CR}$ as well in a young, female population (Petrizzo et al. 2017; Tinsley et al. 2018). This hypothesis should be tested in well-controlled studies to better infer causality. Moreover, future research should provide a detailed description of how RT variables were applied, given the incomplete data regarding RT variables seen in this review. In this context, we recommend providing workout details with the variables identified by Toigo and Boutellier (2006) that have all been shown to affect the adaptation response following repeated bouts of RT.

\section{Male resistance-trained athletes}

Seven studies using male participants (Mitchell et al. 2018; Pardue et al. 2017; Kistler et al. 2014; Dudgeon et al. 2017; Stratton et al. 2020; Schoenfeld et al. 2020; Robinson et al. 2015) and 1 study using mixed-sex groups (Campbell et al. 2020) met inclusion criteria of our review. Except for 2 studies (Dudgeon et al. 2017; Stratton et al. 2020), the remaining 6 studies reported a wide range of lean tissue losses. When evaluating the relationship between lean tissue changes and RT volume in this population, studies reporting low (Dudgeon et al. 2017) [+CARB group] to no loss (Dudgeon et al. 2017) [+ WHEY group] or even an increase (Stratton et al. 2020) in CSA, involved an increased RT volume over time. These findings are supported by a study that increased volume during the first few weeks of the $\mathrm{CR}$ and then reduced RT volume during the final weeks (Mitchell et al. 2018).

Dudgeon et al. (2017) recruited RT athletes with at least 2 years of RT experience and compared lean mass changes when consuming higher versus lower protein diets during CR. The supervised RT protocol included 3-4 sets/exercise with steady RT volume increases throughout the course of the study. The higher protein group fully retained initial lean mass with the control group slightly losing lean mass $[-0.9 \mathrm{~kg}(39.1 \%)]$. Moreover, the study by Stratton et al. (2020) involved recreationally active athletes with "at least 6 months" of RT experience. Participants performed a supervised RT protocol that progressively increased load over time. At study's end, ultrasound measurements revealed a significant increase in $\mathrm{m}$. vastus lateralis and $\mathrm{m}$. biceps brachii CSA. These findings suggest that increasing RT volume could possibly elicit lean tissue accretion in recreationally trained athletes under conditions of CR. The results are in accordance with other studies (Garthe et al. 2011; Longland et al. 2016; Barakat et al. 2020), suggestive of 
a mediating effect of RT experience on lean mass sparing during CR. Consequently, findings using RT beginners or novice athletes cannot be extrapolated to populations who are chronically adapted to RT. Beginners or novice athletes are hypersensitized to RT-induced stimuli, which probably leads to a better preservation or, perhaps even an accretion of lean mass during hypocaloric conditions (Garthe et al. 2011; Longland et al. 2016).

Current data suggest that increasing RT volume over time might have beneficial effects on sparing lean mass during $\mathrm{CR}$ in resistance-trained males, as well. This hypothesis is supported by longitudinal data showing an increase in lean mass $(0.4 \mathrm{~kg})$ during the first 8 weeks of contest preparation ( -260 kcal/day) of resistance-trained men (Mitchell et al. 2018). The athletes trained progressively (total tonnage per week) between week 16 (PRE16) and week 8 (PRE8) (volume increased from 82,500 kg to 94,300 kg). However, when the athletes reduced total volume $(94,300 \mathrm{~kg}$ to $66,600 \mathrm{~kg})$ from week 8 (PRE8) to week 1 (PRE1), a lean mass loss of $-0.5 \mathrm{~kg}$ on average was observed. Similar results were found in the case study by Schoenfeld et al. (2020). Although volume cannot be calculated retrospectively, a high RT volume (range: 1-10 sets/exercise performed 6-7 days/week) was reported over the course of the study with no alterations in lean mass seen during the first 3 months of contest preparation as indicated by multifrequency BIA. This interpretation is supported by the complementary ultrasound measurements (muscle thickness) revealing muscle maintenance until month 5 of the contest preparation. Afterward, muscle thickness measures showed a rapid and severe decline in the last months of preparation. Notably, lean tissue loss coincided with a marked reduction in caloric intake and higher aerobic training volume, whereby the individual achieved extremely low levels of body fat $(<7 \%)$. It can be speculated that lean mass loss might heighten when body fat levels fall to a given minimal threshold, as demonstrated in some (Kistler et al. 2014; Robinson et al. 2015) but not all (Mitchell et al. 2018) studies. Higher aerobic training may also interfere with RT adaptations, especially in highly resistancetrained individuals (Petré et al. 2021; Vechin et al. 2021).

The case studies by Robinson et al. (2015) and Kistler et al. (2014) reported large lean mass losses of approximately $-5.0 \mathrm{~kg}(\sim 43 \%$, skinfolds $)$ and $-6.6 \mathrm{~kg}(\sim 43 \%$, DXA), respectively. The workout routines included 20-25 sets/workout (Kistler et al. 2014) and 4-5 sets/exercise performed twice per week (Robinson et al. 2015), with no information provided about total tonnage lifted, total sets per muscle group per week or any RT volume increases/ decreases over time. Notably, both athletes dieted in a comparably higher deficit with Robinson et al. (2015) equating to $-882 \mathrm{kcal} / \mathrm{day}$ and Kistler et al. (2014) to $\sim-580 \mathrm{kcal} /$ day. Although the study by Robinson et al. (2015) could be categorized as high-volume based on our established qualifications, the extent of lean mass sparing is determined by the interplay of multiple variables (Heymsfield et al. 2011). We propose two possible explanations for the higher observed losses in lean mass in these case studies. First, given the assumption that higher deficits lead to greater lean mass loss (Chaston et al. 2007), we speculate that once the deficit becomes too severe, even anabolic stimuli such as high-volume RT may be unable to counteract diet-induced anabolic resistance (Schoenfeld et al. 2020; Kistler et al. 2014; Robinson et al. 2015; Murphy and Koehler 2020). The total body mass loss exhibited in the examined studies did not necessarily translate into lean mass loss, underscoring total energy deficit as an essential factor in determining lean mass change (Murphy and Koehler 2021). Second, according to the inverted U-shaped relationship of hypertrophy proposed by Schoenfeld et al. (2017b), the individual RT volume could be possibly either not high enough or, alternatively, too high, as RT volume must always be considered in a relative (e.g., compared to the off-season) manner (Scarpelli et al. 2020). If volume is decreased from the off-season to the weight loss phase, as has been previously reported in bodybuilders (Hackett et al. 2013), this conceivably reduces mechanical loading, which in turn may hasten the decrease in lean mass (Hornberger 2011; Vandenburgh et al. 1999; Gao et al. 2018; Breen et al. 2013).

Since important information regarding RT variables often was not reported, calculating total tonnage or sets per muscle group per week was only possible in one study and, hence, precluded us from drawing relevant conclusions in this regard. However, based on the inverted U-shaped relationship between RT volume and muscle hypertrophy, the data appear to suggest that progressively increasing RT volume during $\mathrm{CR}$, either by increasing sets per exercise or the load lifted, might be more effective in ameliorating CR-induced atrophy in male resistance-trained athletes than reducing RT volume. When compared to female athletes, increasing RT volume appears to partially counteract, but does not completely reverse diet-induced perturbations in lean tissue in male athletes. Consequently, studies employing mixed-sex designs (Campbell et al. 2020) could not be taken into account due to reporting only summarized results. Although males and females show a similar RT-induced mTOR activation (Dreyer et al. 2010; Smith et al. 2009), they differ in body composition, muscle phenotype, hormonal actions, and mitochondrial activity (Rosa-Caldwell and Greene 2019; Stapley 2001; Williams et al. 2015), and typically retain more lean mass than their male counterparts during phases of CR. Given that sex differences have already been reported for muscle strength and muscle size in an elderly population (Jones et al. 2021), our findings highlight sex as a significant influencing variable that affects lean tissue change during CR. Thus, we recommend future studies that investigate body composition changes during $\mathrm{CR}$ 
to report sex-differentiated results rather than summarizing results. Although research remains somewhat inconclusive on the topic, it might be speculated that a higher estrogen concentration might contribute to lean mass sparing (Carson and Manolagas 2015; Enns and Tiidus 2010), perhaps due to its anabolic effect on insulin-like growth factor (IGF1) (Olivieri et al. 2014). This hypothesis warrants further investigation.

\section{Possible explanatory mechanisms}

\section{Endocrine factors}

Hormones take part in a complex signaling system and are affected by exogenous stimuli such as CR, energy availability (Loucks and Thuma 2003; Mountjoy et al. 2018), and physical activity (de Alcantara Borba et al. 2020; Kraemer and Ratamess 2005). For instance, CR induces endocrine changes that may negatively affect protein balance and ultimately contributes to lean mass loss. In this case, the body conceivably conserves energy for more important physiological processes (Trexler et al. 2014). Since IGF-1 data were not reported in the studies included in this review, we solely focused on testosterone changes during CR.

Testosterone is considered a key anabolic hormone that possesses a variety of ergogenic, anabolic, and anti-catabolic properties (Kraemer et al. 2020). Several authors reported lean mass loss after a chronic drop in testosterone in the absence of RT during CR (Friedl et al. 2000; Karila et al. 2008); alternatively, lean mass sparing is reported with nonsignificant testosterone changes (Huovinen et al. 2015), suggesting a potential role of testosterone on the extent of lean mass sparing during CR. Dietary interventions, including a high-protein approach, are not able to attenuate the testosterone decline during CR (Henning et al. 2014); rather, the drop seems to be energy-dependent (Karila et al. 2008; Mero et al. 2010; Longland et al. 2016) and must be interpreted in the context of other anabolic hormones such as IGF1(Sculthorpe et al. 2012). In the context of RT, androgen receptor content correlates with an increase in lean mass and $\mathrm{m}$. vastus lateralis type 1 and 2 CSA, respectively, during eucaloric conditions (Morton et al. 2018).

With respect to the studies compiled in this review, 6 studies investigated testosterone change during energy deficit with mixed results. In a case study involving self-reported "moderate-volume" RT (Rohrig et al. 2017), the female athlete's testosterone level did not drop during contest preparation. In this case, no lean mass loss was observed. Stratton et al. (2020) reported that testosterone concentration changed significantly by a non-consequential amount of $-6.6 \mathrm{ng} /$ $\mathrm{dL}$ (time-restricted feeding) and $-1.1 \mathrm{ng} / \mathrm{dL}$ (normal daily feeding), respectively, with their participants ultimately increasing CSA during CR; RT load was increased during the course of the study. Moreover, no statistical difference in testosterone change was seen in the first 8 weeks of contest preparation in the study by Mitchell et al. (2018), coinciding with increased RT volume. Contrarily, other research reported that testosterone levels dropped in females (Hulmi et al. 2016), with contradictory lean mass changes reported between DXA and MFBIA, and males (Schoenfeld et al. 2020; Pardue et al. 2017). The CR-induced drop in testosterone levels might negatively affect MAPK/ERK1/2 (Dent et al. 2012; Hamdi and Mutungi 2010), mTOR and Akt signaling, as well as androgen receptor activation (BasualtoAlarcón et al. 2013), and thus possibly have a detrimental effect on protein balance (Rossetti et al. 2017).

Although higher acute hormonal concentrations may enhance the anabolic milieu and hence help to spare lean mass (Pritchard et al. 1999; Kraemer et al. 2020), acute postexercise hormonal elevations are not necessarily reflected in the MPS response (West et al. 2009). Moreover, methodological difficulties such as measurement timing, circadian rhythm, blood volume changes, and hormonal interactions with binding proteins (Craig et al. 2008; Kraemer et al. 2016) make inter-study comparisons challenging. While mediated by a plethora of variables such as energy deficit, energy availability, and sleep quality, the data compiled in this review may suggest a link between higher volume RT, testosterone-level preservation, and lean mass sparing during CR. Nevertheless, this hypothesis remains speculative and warrants further study.

\section{Intracellular pathways}

Lean mass changes are determined by the dynamic balance between MPS and protein breakdown (Biolo et al. 1995; Phillips et al. 1997). Termed as protein turnover, this ratio is affected by many variables such as energy and nutrient availability, growth-related hormones, sleep status, and mechanical loading (Areta et al. 2014; Hoppeler 2016; Pasiakos and Carbone 2014). In the perspective of the latter, high-volume RT elicits reactions in metabolic, endocrine, nervous, and musculoskeletal systems (Kraemer and Ratamess 2004).

The mechanistic target of rapamycin (mTOR) functions as a molecular nodal point that modulates the magnitude and duration of MPS (Hoppeler 2016). During CR, activation of mTORC1 and its downstream targets, as well as MPS is reduced, while proteolysis appears to be increased (Margolis et al. 2016; Carbone et al. 2014; Berryman et al. 2017); however, the results in this regard are somewhat conflicting (Carbone et al. 2019). Without any counteracting stimuli (e.g., RT), attenuation of MPS ultimately leads to a negative net protein balance and, hence, to lean tissue loss (Roth et al. 2021; Pasiakos et al. 2013). This is supported by the data of athletes taking performance-enhancing drugs who, due to ergogenic effects on protein turnover, do not show 
significant lean tissue loss (Pasiakos et al. 2019; de Souza et al. 2018; Howard et al. 2020). Although RT is widely recognized as a potent countermeasure against CR-induced alterations, lean tissue loss is also often reported (Weinheimer et al. 2010).

A change in the protein translation process is believed to be a possible reason for the reduced MPS response to either nutritional or mechanical stimuli during $\mathrm{CR}$, conceivably as an adaptive response by the body to selectively synthesize new proteins depending on cell needs (e.g., surviving function; Margolis et al. 2016; Miller et al. 2012; Carbone et al. 2012). While higher volume RT increases intracellular anabolic signaling during eucaloric conditions (Burd et al. 2010; Terzis et al. 2010; Hulmi et al. 2012; Ahtiainen et al. 2015), similar findings have been reported for CR (Areta et al. 2014). Although resting postabsorptive MPS was reported to be lower during CR (30 kcal/ $\left./ \mathrm{kg}^{-1} \mathrm{FFM}\right)$ when compared to energy balance (Areta et al. 2014), high-volume RT (6 sets $\times 8$ repetitions) elevated MPS to values observed at rest in energy balance, along with further increases after protein supplementation. The study included resistance-trained ath-

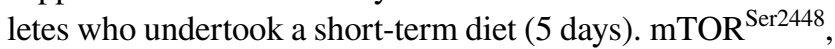
$\mathrm{Akt}^{\mathrm{Ser} 473}, \mathrm{p} 70 \mathrm{~S} 6 \mathrm{~K}^{\mathrm{Thr} 389}$, and $\mathrm{rpS6}^{\mathrm{Ser} 236 / 237}$ phosphorylation were restored above resting energy balance baseline levels and no differences were seen in AMPK, 4E-BP1, or eEF2 phosphorylation. Contrarily, lower postabsorptive $\mathrm{Akt}^{\mathrm{Ser} 473}$ phosphorylation as well as lower postprandial p70s6k ${ }^{\text {Ser424/ }}$ Thr421 phosphorylation (similar postprandial p70s6k levels at Thr389) were observed by Pasiakos et al. (2013), who investigated the effect of different protein intakes in physically active individuals undergoing CR. Herein, low-volume and low-intensity resistive type exercise was performed to maintain physical fitness. In contrast to Areta et al. (2014), lower phosphorylation levels of $\mathrm{Akt}^{\mathrm{Ser} 473}$ and $\mathrm{p} 70 \mathrm{~s} 6 \mathrm{k}^{\text {Ser424/ }}$ ${ }^{T h r 421}$ have been reported. Since CR was comparable in both studies and high-protein approaches were followed, differences in RT volume might be an explanation for the different signaling responses. In addition to RT volume, differences in intensity of effort (proximity to failure) should be considered a potential alternative theory given that proximity to failure might affect hypertrophy in resistance-trained athletes (Grgic et al. 2021).

Although evidence remains preliminary, it appears that multi-set protocols lead to a pronounced upregulation of intracellular anabolic signaling in resistance-trained athletes when compared with low-volume resistive type exercise during CR. However, although intracellular data appear to support the proposed benefits of higher RT volume on lean tissue sparing, further studies are warranted to test this hypothesis.

\section{Conclusion and limitations}

The findings of this review suggest that reducing RT volume during CR (van der Ploeg et al. 2001; Vargas-Molina et al. 2020; Mitchell et al. 2018) may negatively affect lean tissue sparing in resistance-trained individuals. Based on the included studies, there is insufficient evidence to conclude that a higher RT volume better spares lean mass during CR, although the available data seem to favor high-volume RT in female athletes under these circumstances. Studies examining resistance-trained males are less conclusive, with 1 study reporting substantial lean mass loss despite being referenced as high-volume; however, the data appear to suggest that systematically increasing volume during CR may enhance the anabolic milieu when compared to reducing RT volume. Hence, increasing resistance training volume might be a promising approach to maximize lean tissue sparing during CR (Fig. 3). Possible effects seem to be mediated by training experience, pre-diet volume, energy deficit, body fat, and concurrent aerobic training. Accordingly, advanced lifters or athletes adapted to high mechanical loading protocols (e.g., powerlifters) might require more volume compared to recreationally trained athletes (Stratton et al. 2020), similar to what has been reported for muscle strength gains (Peterson et al. 2005).

When stratified by sex, our findings also indicate that women tend to retain more lean mass compared to males when using higher volume RT during CR. However, randomized controlled trials on the topic are lacking (Fagerberg 2018; Helms et al. 2015a). Furthermore, methodological differences (e.g., protein amount, RT experience, initial fat mass, or volume quantification), study quality, and the varied assessment techniques (4C, DXA, BIA, ADP, UWW, skinfolds, and sonography) confound the ability to draw strong conclusions. Since data regarding manipulation of RT variables were incomplete in most of the included studies, findings need to be interpreted with caution. Based on the 2791 papers screened, only 15 studies met inclusion criteria and, hence, were included in qualitative analysis. However, where applicable, relevant information from other studies was incorporated into the conclusions drawn herein.

Contrary to our conclusion, athletes are often instructed to reduce volume during phases of CR (Gentil 2015; Chaouachi et al. 2009; Meckel et al. 2008). This practice is typically justified by the claim of higher recovery demands under conditions of low-energy availability and often referenced with the study of Bickel and colleagues (2011), who demonstrated that young, intermediate-experienced athletes can preserve lean mass during eucaloric conditions when training with approximately one-third of their original volume. However, CR is associated with a suppression of anabolic and anti-catabolic stimuli, as well as 


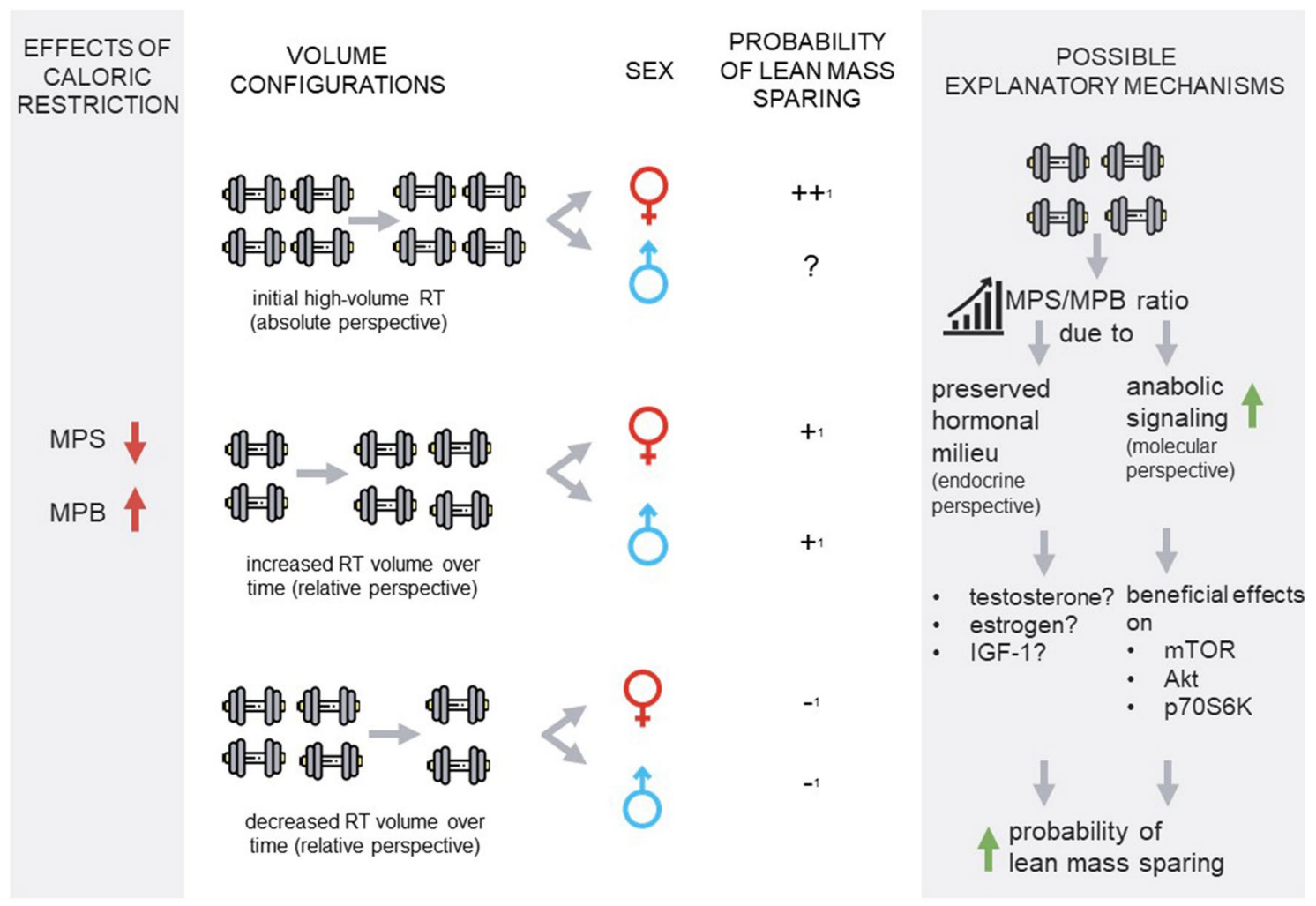

Fig. 3 Overview of review findings. ${ }^{1}$ supported by preliminary evidence; plus/minus demonstrates probability of lean mass sparing. This chart was created using images from flaticon.com (Good Ware / Freepik). Green color indicates a beneficial effect on lean mass

a heightened catabolic milieu. From an intracellular signaling perspective, findings of eucaloric and hypercaloric studies cannot be extrapolated to hypocaloric conditions due to skeletal muscle probably becoming less sensitive to nutritional and mechanical stimuli during CR (Murphy and Koehler 2020). Consequently, RT volume should not necessarily be decreased during phases of prolonged CR.

It is important to note that our conclusions are based on correlational data, which precludes the ability to draw strong causal inferences. Future research should focus on conducting randomized controlled interventions that directly compare higher versus lower RT volume protocols during periods of $\mathrm{CR}$ to better understand the cause-effect relationship between training volume and energy availability.

Author contributions CR, BJS, and MB drafted, critically reviewed, and revised the manuscript for important intellectual content. All authors contributed to manuscript revision, read, and approved the submitted version.

Funding Open Access funding enabled and organized by Projekt DEAL. This review was not funded. Publication fees are paid by Goethe-University Frankfurt/Main, Germany.

sparing; red color indicates a detrimental effect on lean mass sparing, MPS muscle protein synthesis, $M P B$ muscle protein breakdown, $R T$ resistance training

Availability of data and materials Not applicable.

\section{Declarations}

Conflict of interest BJS serves on the scientific advisory board for Tonal Corporation, a manufacturer of fitness equipment. The other authors (CR and $\mathrm{MB}$ ) declare that the submitted work was carried out in the absence of any personal, professional, or financial relationships that could potentially be construed as a conflict of interest.

Ethics approval Not applicable.

Consent to participate Not applicable.

Consent for publication $\mathrm{CR}$, BJS, and MB give the publisher the permission to publish this review.

Open Access This article is licensed under a Creative Commons Attribution 4.0 International License, which permits use, sharing, adaptation, distribution and reproduction in any medium or format, as long as you give appropriate credit to the original author(s) and the source, provide a link to the Creative Commons licence, and indicate if changes were made. The images or other third party material in this article are included in the article's Creative Commons licence, unless indicated otherwise in a credit line to the material. If material is not included in the article's Creative Commons licence and your intended use is not permitted by statutory regulation or exceeds the permitted use, you will 
need to obtain permission directly from the copyright holder. To view a copy of this licence, visit http://creativecommons.org/licenses/by/4.0/.

\section{References}

ACSM (2009) American college of sports medicine position stand. Progression models in resistance training for healthy adults. Med Sci Sports Exerc 41(3):687-708. https://doi.org/10.1249/MSS. 0b013e3181915670

Ahtiainen JP, Walker S, Silvennoinen M, Kyröläinen H, Nindl BC, Häkkinen K, Nyman K, Selänne H, Hulmi JJ (2015) Exercise type and volume alter signaling pathways regulating skeletal muscle glucose uptake and protein synthesis. Eur J Appl Physiol 115(9):1835-1845. https://doi.org/10.1007/s00421-015-3155-3

Antonio J, Knafo S, Kenyon M, Ali A, Carson C, Ellerbroek A, Weaver C, Roberts J, Peacock CA, Tartar JL (2019) Assessment of the FTO gene polymorphisms (rs1421085, rs17817449 and rs9939609) in exercise-trained men and women. The effects of a 4-week hypocaloric diet. J Int Soc Sports Nutr 16(1):36. https:// doi.org/10.1186/s12970-019-0307-6

Areta JL, Burke LM, Camera DM, West DWD, Crawshay S, Moore DR, Stellingwerff T, Phillips SM, Hawley JA, Coffey VG (2014) Reduced resting skeletal muscle protein synthesis is rescued by resistance exercise and protein ingestion following short-term energy deficit. Am J Physiol Endocrinol Metabol 306(8):E989E997. https://doi.org/10.1152/ajpendo.00590.2013

Bamman MM, Hunter GR, Newton LE, Roney RK, Khaled MA (1993) Changes in body composition, diet, and strength of bodybuilders during the 12 weeks prior to competition. J Sports Med Phys Fitness 33(4):383-391

Barakat C, Pearson J, Escalante G, Campbell B, de Souza EO (2020) Body Recomposition: can trained individuals build muscle and lose fat at the same time? Strength Condition J 42(5):7-21. https://doi.org/10.1519/SSC.0000000000000584

Basualto-Alarcón C, Jorquera G, Altamirano F, Jaimovich E, Estrada M (2013) Testosterone signals through mTOR and androgen receptor to induce muscle hypertrophy. Med Sci Sports Exerc 45(9):1712-1720. https://doi.org/10.1249/MSS.0b013e3182 $8 \mathrm{cf} 5 \mathrm{f} 3$

Baz-Valle E, Fontes-Villalba M, Santos-Concejero J (2018) Total number of sets as a training volume quantification method for muscle hypertrophy. A systematic review. J Strength Condition Res https://doi.org/10.1519/JSC.0000000000002776

Bazyler CD, Mizuguchi S, Zourdos MC, Sato K, Kavanaugh AA, DeWeese BH, Breuel KF, Stone MH (2018) Characteristics of a national level female weightlifter peaking for competition. a case study. J Strength Condition Res 32(11):3029-3038. https://doi. org/10.1519/JSC.0000000000002379

Berryman CE, Sepowitz JJ, McClung HL, Lieberman HR, Farina EK, McClung JP, Ferrando AA, Pasiakos SM (2017) Supplementing an energy adequate, higher protein diet with protein does not enhance fat-free mass restoration after short-term severe negative energy balance. J Appl Physiol (Bethesda, Md.: 1985) 122(6):1485-1493. https://doi.org/10.1152/japplphysiol.01039. 2016

Bickel CS, Cross JM, Bamman MM (2011) Exercise dosing to retain resistance training adaptations in young and older adults. Med Sci Sports Exerc 43(7):1177-1187. https://doi.org/10.1249/MSS. 0b013e318207c15d

Biolo G, Maggi SP, Williams BD, Tipton KD, Wolfe RR (1995) Increased rates of muscle protein turnover and amino acid transport after resistance exercise in humans. Am J Physiol 268(3 Pt 1):E514-E520. https://doi.org/10.1152/ajpendo.1995.268.3.E514
Bouchard DR, Soucy L, Sénéchal M, Dionne IJ, Brochu M (2009) Impact of resistance training with or without caloric restriction on physical capacity in obese older women. Menopause (New York, N.Y.) 16(1):66-72. https://doi.org/10.1097/gme.0b013 e31817dacf7

Breen L, Stokes KA, Churchward-Venne TA, Moore DR, Baker SK, Smith K, Atherton PJ, Phillips SM (2013) Two weeks of reduced activity decreases leg lean mass and induces "anabolic resistance" of myofibrillar protein synthesis in healthy elderly. J Clin Endocrinol Metab 98(6):2604-2612. https://doi.org/10.1210/jc. 2013-1502

Burd NA, Holwerda AM, Selby KC, West DWD, Staples AW, Cain NE, Cashaback JGA, Potvin JR, Baker SK, Phillips SM (2010) Resistance exercise volume affects myofibrillar protein synthesis and anabolic signalling molecule phosphorylation in young men. J Physiol 588(Pt 16):3119-3130. https://doi.org/10.1113/jphys iol.2010.192856

Campbell BI, Aguilar D, Colenso-Semple LM, Hartke K, Fleming AR, Fox CD, Longstrom JM, Rogers GE, Mathas DB, Wong V, Ford S, Gorman J (2020) Intermittent energy restriction attenuates the loss of fat free mass in resistance trained individuals a randomized controlled trial. JFMK 5(1):19. https://doi.org/10. 3390/jfmk5010019

Carbone JW, McClung JP, Pasiakos SM (2012) Skeletal muscle responses to negative energy balance. Effects of dietary protein. Adv Nutr (Bethesda, Md.) 3(2):119-126. https://doi.org/10.3945/ an.111.001792

Carbone JW, Pasiakos SM, Vislocky LM, Anderson JM, Rodriguez NR (2014) Effects of short-term energy deficit on muscle protein breakdown and intramuscular proteolysis in normal-weight young adults. Applied physiology, nutrition, and metabolism $=$ Physiologie appliquee, nutrition et metabolisme 39(8):960-968. https://doi.org/10.1139/apnm-2013-0433

Carbone JW, McClung JP, Pasiakos SM (2019) Recent advances in the characterization of skeletal muscle and whole-body protein responses to dietary protein and exercise during negative energy balance. Adv Nutr (Bethesda, Md.) 10(1):70-79. https://doi.org/ 10.1093/advances/nmy087

Carson JA, Manolagas SC (2015) Effects of sex steroids on bones and muscles. Similarities, parallels, and putative interactions in health and disease. Bone 80:67-78. https://doi.org/10.1016/j. bone.2015.04.015

Cava E, Yeat NC, Mittendorfer B (2017) Preserving Healthy Muscle during Weight Loss. Advances in nutrition (Bethesda, Md.) 8(3):511-519. doi: https://doi.org/10.3945/an.116.014506

Chaouachi A, Leiper JB, Souissi N, Coutts AJ, Chamari K (2009) Effects of ramadan intermittent fasting on sports performance and training: a review. Int J Sports Physiol Perform 4(4):419434. https://doi.org/10.1123/ijspp.4.4.419

Chaston TB, Dixon JB, O'Brien PE (2007) Changes in fat-free mass during significant weight loss. A systematic review. Int J Obes (2005) 31(5):743-750. https://doi.org/10.1038/sj.ijo.0803483

Chatterton S, Zinn C, Helms ER, Storey A (2017) The effect of an 8 -week low carbohydrate high fat (LCHF) diet in sub-elite Olympic weightlifters on strength, body composition, mental state and adherence. A pilot-case-study. J Austral Strength Condition 25(2):6-13

Churchward-Venne TA, Burd NA, Phillips SM (2012) Nutritional regulation of muscle protein synthesis with resistance exercise: strategies to enhance anabolism. Nutr Metab 9(1):40. https://doi. org/10.1186/1743-7075-9-40

Churchward-Venne TA, Murphy CH, Longland TM, Phillips SM (2013) Role of protein and amino acids in promoting lean mass accretion with resistance exercise and attenuating lean mass loss 
during energy deficit in humans. Amino Acids 45(2):231-240. https://doi.org/10.1007/s00726-013-1506-0

Craig SK, Byrnes WC, Fleck SJ (2008) Plasma volume during weight lifting. Int J Sports Med 29(2):89-95. https://doi.org/10. 1055/s-2007-965108

Damas F, Phillips S, Vechin FC, Ugrinowitsch C (2015) A review of resistance training-induced changes in skeletal muscle protein synthesis and their contribution to hypertrophy. Sports Med (Auckland, N.Z.) 45(6):801-807. https://doi.org/10.1007/ s40279-015-0320-0

de Alcantara Borba D, da Silva AE, Rosa JPP, Facundo LA, Costa CMA, Silva AC, Narciso FV, Silva A, de Mello MT (2020) Can IGF-1 serum levels really be changed by acute physical exercise? a systematic review and meta-analysis. J Phys Act Health 17(5):575-584. https://doi.org/10.1123/jpah.2019-0453

de Souza D, Santos J, de Jesus D, Gentil P (2018) Biochemical profile and body composition alteration of amateur bodybuilders during the pre-contest period. JFMK 3(2):26. https://doi.org/10.3390/ jfmk3020026

Dent JR, Fletcher DK, McGuigan MR (2012) Evidence for a nongenomic action of testosterone in skeletal muscle which may improve athletic performance: implications for the female athlete. J Sports Sci Med 11(3):363-370

Dreyer HC, Fujita S, Glynn EL, Drummond MJ, Volpi E, Rasmussen BB (2010) Resistance exercise increases leg muscle protein synthesis and mTOR signalling independent of sex. Acta Physiol (oxf) 199(1):71-81. https://doi.org/10.1111/j.1748-1716.2010. 02074.x

Dudgeon WD, Kelley EP, Scheett TP (2017) Effect of whey protein in conjunction with a caloric-restricted diet and resistance training. J Strength Cond Res 31(5):1353-1361. https://doi.org/10.1519/ JSC.0000000000001196

Dudgeon WD, Kelley EP, Scheett TP (2016) In a single-blind, matched group design. Branched-chain amino acid supplementation and resistance training maintains lean body mass during a caloric restricted diet. J Int Soc Sports Nutr 13:1. https://doi.org/10. 1186/s12970-015-0112-9

Durguerian A, Bougard C, Drogou C, Sauvet F, Chennaoui M, Filaire E (2016) Weight Loss, Performance and Psychological Related States in High-level Weightlifters. Int J Sports Med 37(3):230 238. https://doi.org/10.1055/s-0035-1555852

Enns DL, Tiidus PM (2010) The influence of estrogen on skeletal muscle: sex matters. Sports Med (Auckland, N.Z.) 40(1):41-58. https://doi.org/10.2165/11319760-000000000-00000

Fagerberg P (2018) Negative consequences of low energy availability in natural male bodybuilding. A review. Int J Sport Nutr Exerc Metabol 28(4):385-402. https://doi.org/10.1123/ijsnem. 2016-0332

Figueiredo VC, Salles BF de, Trajano GS (2018) Volume for muscle hypertrophy and health outcomes. The most effective variable in resistance training. Sports Med (Auckland, N.Z.) 48(3):499-505. https://doi.org/10.1007/s40279-017-0793-0

Friedl KE, Moore RJ, Hoyt RW, Marchitelli LJ, Martinez-Lopez LE, Askew EW (2000) Endocrine markers of semistarvation in healthy lean men in a multistressor environment. J Appl Physiol (Bethesda, Md.: 1985) 88(5):1820-1830 https://doi.org/10.1152/ jappl.2000.88.5.1820

Gao Y, Arfat Y, Wang H, Goswami N (2018) Muscle atrophy induced by mechanical unloading: mechanisms and potential countermeasures. Front Physiol 9:235. https://doi.org/10.3389/fphys. 2018.00235

Gardner CD, Trepanowski JF, Del Gobbo LC, Hauser ME, Rigdon J, Ioannidis JPA, Desai M, King AC (2018) Effect of low-fat vs low-carbohydrate diet on 12-month weight loss in overweight adults and the association with genotype pattern or insulin secretion The DIETFITS Randomized Clinical Trial. JAMA 319(7):667-679. https://doi.org/10.1001/jama.2018.0245

Garthe I, Raastad T, Refsnes PE, Koivisto A, Sundgot-Borgen J (2011) Effect of two different weight-loss rates on body composition and strength and power-related performance in elite athletes. Int J Sport Nutr Exerc Metab 21(2):97-104

Gentil P, de Lira CAB, Paoli A, Dos Santos JAB, da Silva RDT, Junior JRP, da Silva EP, Magosso RF (2017) Nutrition, pharmacological and training strategies adopted by six bodybuilders. Case report and critical review. Eur J Transl Myol 27(1):6247. https://doi. org/10.4081/ejtm.2017.6247

Gentil P (2015) A nutrition and conditioning intervention for natural bodybuilding contest preparation. Observations and suggestions. J Int Soc Sports Nutr 12:50. https://doi.org/10.1186/ s12970-015-0111-x

Greene DA, Varley BJ, Hartwig TB, Chapman P, Rigney M (2018) A low-carbohydrate ketogenic diet reduces body mass without compromising performance in powerlifting and olympic weightlifting athletes. J Strength Cond Res 32(12):3373-3382. https://doi.org/10.1519/JSC.0000000000002904

Greenhaff PL, Karagounis LG, Peirce N, Simpson EJ, Hazell M, Layfield R, Wackerhage H, Smith K, Atherton P, Selby A, Rennie MJ (2008) Disassociation between the effects of amino acids and insulin on signaling, ubiquitin ligases, and protein turnover in human muscle. Am J Physiol Endocrinol Metabol 295(3):E595-E604. https://doi.org/10.1152/ajpendo.90411. 2008

Greenhalgh T, Peacock R (2005) Effectiveness and efficiency of search methods in systematic reviews of complex evidence. Audit of primary sources. BMJ (clinical Research Ed) 331(7524):1064 1065. https://doi.org/10.1136/bmj.38636.593461.68

Grgic J, Schoenfeld BJ, Orazem J, Sabol F (2021) Effects of resistance training performed to repetition failure or non-failure on muscular strength and hypertrophy: A systematic review and meta-analysis. J Sport Health Sci. https://doi.org/10.1016/j.jshs. 2021.01.007

Gwin JA, Church DD, Hatch-McChesney A, Howard EE, Carrigan CT, Murphy NE, Wilson MA, Margolis LM, Carbone JW, Wolfe RR, Ferrando AA, Pasiakos SM (2020a) Effects of high versus standard essential amino acid intakes on whole-body protein turnover and mixed muscle protein synthesis during energy deficit: A randomized, crossover study. Clin Nutr (Edinburgh, Scotland). https://doi.org/10.1016/j.clnu.2020.07.019

Gwin JA, Church DD, Wolfe RR, Ferrando AA, Pasiakos SM (2020b) Muscle protein synthesis and whole-body protein turnover responses to ingesting essential amino acids, intact protein, and protein-containing mixed meals with considerations for energy deficit. Nutrients. https://doi.org/10.3390/nu12082457

Hackett DA, Johnson NA, Chow C-M (2013) Training practices and ergogenic aids used by male bodybuilders. J Strength Cond Res 27(6):1609-1617. https://doi.org/10.1519/JSC.0b013e3182 $71272 \mathrm{a}$

Halliday TM, Loenneke JP, Davy BM (2016) Dietary intake, body composition, and menstrual cycle changes during competition preparation and recovery in a drug-free figure competitor. A case study. Nutrients. https://doi.org/10.3390/nu8110740

Hamdi MM, Mutungi G (2010) Dihydrotestosterone activates the MAPK pathway and modulates maximum isometric force through the EGF receptor in isolated intact mouse skeletal muscle fibres. J Physiol 588(Pt 3):511-525. https://doi.org/10.1113/ jphysiol.2009.182162

Helms ER, Zinn C, Rowlands DS, Brown SR (2014) A systematic review of dietary protein during caloric restriction in resistance trained lean athletes. A case for higher intakes. Int J Sport Nutr Exerc Metabol 24(2):127-138. https://doi.org/10.1123/ijsnem. 2013-0054 
Helms ER, Fitschen PJ, Aragon AA, Cronin J, Schoenfeld BJ (2015a) Recommendations for natural bodybuilding contest preparation. Resistance and cardiovascular training. J Sports Med Phys Fitness 55(3):164-178

Helms ER, Zinn C, Rowlands DS, Naidoo R, Cronin J (2015b) Highprotein, low-fat, short-term diet results in less stress and fatigue than moderate-protein moderate-fat diet during weight loss in male weightlifters. A pilot study. Int J Sport Nutr Exerc Metabol 25(2):163-170. https://doi.org/10.1123/ijsnem.2014-0056

Henning PC, Margolis LM, McClung JP, Young AJ, Pasiakos SM (2014) High protein diets do not attenuate decrements in testosterone and IGF-I during energy deficit. Metabolism 63(5):628-632. https://doi.org/10.1016/j.metabol.2014.02.007

Heymsfield SB, Thomas D, Nguyen AM, Peng JZ, Martin C, Shen W, Strauss B, Bosy-Westphal A, Muller MJ (2011) Voluntary weight loss. Systematic review of early phase body composition changes. Obes Rev 12(5):e348-e361. https://doi.org/10. 1111/j.1467-789X.2010.00767.x

Hickson JF, Johnson TE, Lee W, Sidor RJ (1990) Nutrition and the precontest preparations of a male bodybuilder. J Am Diet Assoc 90(2):264-267

Hoppeler H (2016) Molecular networks in skeletal muscle plasticity. J Exp Biol 219(Pt 2):205-213. https://doi.org/10.1242/jeb. 128207

Hornberger TA (2011) Mechanotransduction and the regulation of mTORC1 signaling in skeletal muscle. Int J Biochem Cell Biol 43(9):1267-1276. https://doi.org/10.1016/j.biocel.2011.05.007

Howard EE, Margolis LM, Berryman CE, Lieberman HR, Karl JP, Young AJ, Montano MA, Evans WJ, Rodriguez NR, Johannsen NM, Gadde KM, Harris MN, Rood JC, Pasiakos SM (2020) Testosterone supplementation upregulates androgen receptor expression and translational capacity during severe energy deficit. Am J Physiol Endocrinol Metabol 319(4):E678-E688. https://doi.org/ 10.1152/ajpendo.00157.2020

Hudson JL, Wang Y, Bergia Iii RE, Campbell WW (2020) Protein intake greater than the rda differentially influences whole-body lean mass responses to purposeful catabolic and anabolic stressors: a systematic review and meta-analysis. Adv Nutr (Bethesda, Md.) 11(3):548-558. https://doi.org/10.1093/advances/nmz106

Hulmi JJ, Walker S, Ahtiainen JP, Nyman K, Kraemer WJ, Häkkinen $\mathrm{K}$ (2012) Molecular signaling in muscle is affected by the specificity of resistance exercise protocol. Scand J Med Sci Sports 22(2):240-248. https://doi.org/10.1111/j.1600-0838.2010. 01198.x

Hulmi JJ, Isola V, Suonpää M, Järvinen NJ, Kokkonen M, Wennerström A, Nyman K, Perola M, Ahtiainen JP, Häkkinen K (2016) The effects of intensive weight reduction on body composition and serum hormones in female fitness competitors. Front Physiol 7:689. https://doi.org/10.3389/fphys.2016.00689

Huovinen HT, Hulmi JJ, Isolehto J, Kyröläinen H, Puurtinen R, Karila T, Mackala K, Mero AA (2015) Body composition and power performance improved after weight reduction in male athletes without hampering hormonal balance. J Strength Cond Res 29(1):29-36. https://doi.org/10.1519/JSC.0000000000000619

Israetel M, Feather J, Faleiro TV, Juneau C-E (2019) Mesocycle progression in hypertrophy. Strength Condition J. https://doi.org/10. 1519/SSC.0000000000000518

Jäger R, Kerksick CM, Campbell BI, Cribb PJ, Wells SD, Skwiat TM, Purpura M, Ziegenfuss TN, Ferrando AA, Arent SM, Smith-Ryan AE, Stout JR, Arciero PJ, Ormsbee MJ, Taylor LW, Wilborn CD, Kalman DS, Kreider RB, Willoughby DS, Hoffman JR, Krzykowski JL, Antonio J (2017) International society of sports nutrition position stand. Protein and exercise. J Int Soc Sports Nutr 14:20. https://doi.org/10.1186/s12970-017-0177-8

Jones MD, Wewege MA, Hackett DA, Keogh JWL, Hagstrom AD (2021) Sex differences in adaptations in muscle strength and size following resistance training in older adults: a systematic review and meta-analysis. Sports Med (Auckland, N.Z.) 51(3):503-517. https://doi.org/10.1007/s40279-020-01388-4

Karila TAM, Sarkkinen P, Marttinen M, Seppälä T, Mero A, Tallroth K (2008) Rapid weight loss decreases serum testosterone. Int J Sports Med 29(11):872-877. https://doi.org/10.1055/s-20081038604

Kistler BM, Fitschen PJ, Ranadive SM, Fernhall B, Wilund KR (2014) Case study. Natural bodybuilding contest preparation. Int J Sport Nutr Exerc Metabol 24(6):694-700. https://doi.org/10.1123/ijsnem.2014-0016

Kleiner SM, Bazzarre TL, Litchford MD (1990) Metabolic profiles, diet, and health practices of championship male and female bodybuilders. J Am Diet Assoc 90(7):962-967

Kraemer WJ, Ratamess NA, Hymer WC, Nindl BC, Fragala MS (2020) Growth hormone(s), testosterone, insulin-like growth factors, and cortisol: roles and integration for cellular development and growth with exercise. Front Endocrinol 11:33. https://doi.org/10. 3389/fendo.2020.00033

Kraemer WJ, Ratamess NA (2004) Fundamentals of resistance training. Progression and exercise prescription. Med Sci Sports Exerc 36(4):674-688

Kraemer WJ, Ratamess NA (2005) Hormonal responses and adaptations to resistance exercise and training. Sports Med (Auckland, N.Z.) 35(4):339-361. https://doi.org/10.2165/00007256-20053 5040-00004

Kraemer WJ, Vingren JL, Spiering BA (2016) Endocrine responses to exercise training. In: national strength \& conditioning association (Ed) essentials of strength training, 4. Edition, pp 66-86

Krzysztofik M, Wilk M, Wojdała G, Gołaś A (2019) Maximizing muscle hypertrophy: a systematic review of advanced resistance training techniques and methods. Int J Environm Res Public Health. https://doi.org/10.3390/ijerph16244897

Kümmel J, Kramer A, Giboin L-S, Gruber M (2016) Specificity of balance training in healthy individuals: a systematic review and meta-analysis. Sports Med (Auckland, N.Z.) 46(9):1261-1271. https://doi.org/10.1007/s40279-016-0515-z

Kysel P, Haluzíková D, Doležalová RP, Laňková I, Lacinová Z, Kasperová BJ, Trnovská J, Hrádková V, Mráz M, Vilikus Z, Haluzík M (2020) The influence of cyclical ketogenic reduction diet vs. nutritionally balanced reduction diet on body composition, strength, and endurance performance in healthy young males: a randomized controlled trial. Nutrients. https://doi.org/10.3390/ nu12092832

Longland TM, Oikawa SY, Mitchell CJ, Devries MC, Phillips SM (2016) Higher compared with lower dietary protein during an energy deficit combined with intense exercise promotes greater lean mass gain and fat mass loss. A randomized trial. Am J Clin Nutr 103(3):738-746. https://doi.org/10.3945/ajen.115.119339

Loucks AB, Thuma JR (2003) Luteinizing hormone pulsatility is disrupted at a threshold of energy availability in regularly menstruating women. J Clin Endocrinol Metab 88(1):297-311. https:// doi.org/10.1210/jc.2002-020369

Maclean PS, Bergouignan A, Cornier M-A, Jackman MR (2011) Biology's response to dieting. The impetus for weight regain. Am J Physiol Regul Integr Compar Physiol 301(3):R581-R600. https://doi.org/10.1152/ajpregu.00755.2010

Mäestu J, Jürimäe J, Valter I, Jürimäe T (2008) Increases in ghrelin and decreases in leptin without altering adiponectin during extreme weight loss in male competitive bodybuilders. Metabolism 57(2):221-225. https://doi.org/10.1016/j.metabol.2007.09.004

Mäestu J, Eliakim A, Jürimäe J, Valter I, Jürimäe T (2010) Anabolic and catabolic hormones and energy balance of the male bodybuilders during the preparation for the competition. J Strength Cond Res 24(4):1074-1081. https://doi.org/10.1519/JSC.0b013 e3181cb6fd3 
Maher CG, Sherrington C, Herbert RD, Moseley AM, Elkins M (2003) Reliability of the PEDro scale for rating quality of randomized controlled trials. Phys Ther 83(8):713-721. https://doi.org/10. 1093/ptj/83.8.713

Manore MM, Thompson J, Russo M (1993) Diet and exercise strategies of a world-class bodybuilder. Int J Sport Nutr 3(1):76-86. https:// doi.org/10.1123/ijsn.3.1.76

Margolis LM, Rivas DA, Berrone M, Ezzyat Y, Young AJ, McClung JP, Fielding RA, Pasiakos SM (2016) Prolonged calorie restriction downregulates skeletal muscle mTORC1 signaling independent of dietary protein intake and associated microRNA expression. Front Physiol 7:445. https://doi.org/10.3389/fphys. 2016.00445

Meckel Y, Ismaeel A, Eliakim A (2008) The effect of the Ramadan fast on physical performance and dietary habits in adolescent soccer players. Eur J Appl Physiol 102(6):651-657. https://doi.org/10. 1007/s00421-007-0633-2

Mero AA, Huovinen H, Matintupa O, Hulmi JJ, Puurtinen R, Hohtari H, Am Karila T (2010) Moderate energy restriction with high protein diet results in healthier outcome in women. J Int Soc Sports Nutr 7(1):4. https://doi.org/10.1186/1550-2783-7-4

Mettler S, Mitchell N, Tipton KD (2010) Increased protein intake reduces lean body mass loss during weight loss in athletes. Med Sci Sports Exerc 42(2):326-337. https://doi.org/10.1249/MSS. 0b013e3181b2ef8e

Miller BF, Robinson MM, Bruss MD, Hellerstein M, Hamilton KL (2012) A comprehensive assessment of mitochondrial protein synthesis and cellular proliferation with age and caloric restriction. Aging Cell 11(1):150-161. https://doi.org/10.1111/j.14749726.2011.00769.x

Mitchell L, Slater G, Hackett D, Johnson N, O'Connor H (2018) Physiological implications of preparing for a natural male bodybuilding competition. Eur J Sport Sci 18(5):619-629. https://doi.org/ 10.1080/17461391.2018.1444095

Moberg M, Lindholm ME, Reitzner SM, Ekblom B, Sundberg C-J, Psilander N (2020) Exercise induces different molecular responses in trained and untrained human muscle. Med Sci Sports Exerc 52(8):1679-1690. https://doi.org/10.1249/MSS. 0000000000002310

Moher D, Liberati A, Tetzlaff J, Altman DG (2009) Preferred reporting items for systematic reviews and meta-analyses The PRISMA Statement. BMJ (clinical Research Ed) 339:b2535. https://doi. org/10.1136/bmj.b2535

Moro T, Tinsley G, Bianco A, Marcolin G, Pacelli QF, Battaglia G, Palma A, Gentil P, Neri M, Paoli A (2016) Effects of eight weeks of time-restricted feeding (16/8) on basal metabolism, maximal strength, body composition, inflammation, and cardiovascular risk factors in resistance-trained males. J Transl Med 14(1):290. https://doi.org/10.1186/s12967-016-1044-0

Morton RW, Sato K, Gallaugher MPB, Oikawa SY, McNicholas PD, Fujita S, Phillips SM (2018) Muscle androgen receptor content but not systemic hormones is associated with resistance training-induced skeletal muscle hypertrophy in healthy. Young Men Frontiers in Physiology 9:1373. https://doi.org/10.3389/fphys. 2018.01373

Mountjoy M, Sundgot-Borgen JK, Burke LM, Ackerman KE, Blauwet C, Constantini N, Lebrun C, Lundy B, Melin AK, Meyer NL, Sherman RT, Tenforde AS, Klungland Torstveit M, Budgett R (2018) IOC consensus statement on relative energy deficiency in sport (RED-S). 2018 update. British J Sports Med 52(11):687697. https://doi.org/10.1136/bjsports-2018-099193

Murphy C, Koehler K (2020) Caloric restriction induces anabolic resistance to resistance exercise. Eur J Appl Physiol 120(5):1155-1164. https://doi.org/10.1007/s00421-020-04354-0

Murphy C, Koehler K (2021) Energy deficiency impairs resistance training gains in lean mass but not strength: A meta-analysis and meta-regression. Scand J Med Sci Sports. https://doi.org/ 10.1111/sms. 14075

Newton LE, Hunter G, Bammon M, Roney R (1993) Changes in psychological state and self-reported diet during various phases of training in competitive bodybuilders. J Strength Cond Res 7(3):153-158. https://doi.org/10.1519/00124278-19930 8000-00005

Olivieri F, Ahtiainen M, Lazzarini R, Pöllänen E, Capri M, Lorenzi M, Fulgenzi G, Albertini MC, Salvioli S, Alen MJ, Kujala UM, Borghetti G, Babini L, Kaprio J, Sipilä S, Franceschi C, Kovanen V, Procopio AD (2014) Hormone replacement therapy enhances IGF-1 signaling in skeletal muscle by diminishing miR-182 and miR-223 expressions: a study on postmenopausal monozygotic twin pairs. Aging Cell 13(5):850-861. https://doi.org/10.1111/ acel. 12245

Pardue A, Trexler ET, Sprod LK (2017) Case study. Unfavorable but transient physiological changes during contest preparation in a drug-free male bodybuilder. Int J Sport Nutr Exerc Metabol 27(6):550-559. https://doi.org/10.1123/ijsnem.2017-0064

Pasiakos SM, Carbone JW (2014) Assessment of skeletal muscle proteolysis and the regulatory response to nutrition and exercise. IUBMB Life 66(7):478-484. https://doi.org/10.1002/iub.1291

Pasiakos SM, Margolis LM, McClung JP, Cao JJ, Whigham LD, Combs GF (2005) Young AJ (2014) Whole-body protein turnover response to short-term high-protein diets during weight loss: a randomized controlled trial. Int J Obes 38(7):1015-1018. https://doi.org/10.1038/ijo.2013.197

Pasiakos SM, Vislocky LM, Carbone JW, Altieri N, Konopelski K, Freake HC, Anderson JM, Ferrando AA, Wolfe RR, Rodriguez NR (2010) Acute energy deprivation affects skeletal muscle protein synthesis and associated intracellular signaling proteins in physically active adults. J Nutr 140(4):745-751. https://doi.org/ 10.3945/jn.109.118372

Pasiakos SM, Berryman CE, Karl JP, Lieberman HR, Orr JS, Margolis LM, Caldwell JA, Young AJ, Montano MA, Evans WJ, Vartanian O, Carmichael OT, Gadde KM, Johannsen NM, Beyl RA, Harris MN, Rood JC (2019) Effects of testosterone supplementation on body composition and lower-body muscle function during severe exercise- and diet-induced energy deficit. A proof-of-concept, single centre, randomised, double-blind, controlled trial. EBioMedicine 46:411-422. https://doi.org/10.1016/j.ebiom.2019.07. 059

Pasiakos SM, Cao JJ, Margolis LM, Sauter ER, Whigham LD, McClung JP, Rood JC, Carbone JW, Combs GF, Young AJ (2013) Effects of high-protein diets on fat-free mass and muscle protein synthesis following weight loss A randomized controlled trial. FASEB J 27(9):3837-3847. https://doi.org/10.1096/ fj. 13-230227

Peterson MD, Rhea MR, Alvar BA (2005) Applications of the doseresponse for muscular strength development. A review of metaanalytic efficacy and reliability for designing training prescription. J Strength Condition Res 19(4):950-958. https://doi.org/ 10.1519/R-16874.1

Petré H, Hemmingsson E, Rosdahl H, Psilander N (2021) Development of maximal dynamic strength during concurrent resistance and endurance training in untrained, moderately trained, and trained individuals: a systematic review and meta-analysis. Sports Mede (Auckland, N.Z.). https://doi.org/10.1007/s40279-021-01426-9

Petrizzo J, DiMenna FJ, Martins K, Wygand J, Otto RM (2017) Case study the effect of 32 weeks of figure-contest preparation on a self-proclaimed drug-free female's lean body and bone mass. Int J Sport Nutr Exerc Metabol 27(6):543-549. https://doi.org/10. 1123/ijsnem.2016-0313

Phillips SM, Tipton KD, Aarsland A, Wolf SE, Wolfe RR (1997) Mixed muscle protein synthesis and breakdown after resistance exercise 
in humans. Am J Physiol 273(1 Pt 1):E99-107. https://doi.org/ 10.1152/ajpendo.1997.273.1.E99

Philpott JD, Bootsma NJ, Rodriguez-Sanchez N, Hamilton DL, MacKinlay E, Dick J, Mettler S, Galloway SDR, Tipton KD, Witard OC (2019) Influence of fish oil-derived n-3 fatty acid supplementation on changes in body composition and muscle strength during short-term weight loss in resistance-trained men. Front Nutr 6:102. https://doi.org/10.3389/fnut.2019.00102

Pritchard J, Després JP, Gagnon J, Tchernof A, Nadeau A, Tremblay A, Bouchard C (1999) Plasma adrenal, gonadal, and conjugated steroids following long-term exercise-induced negative energy balance in identical twins. Metabol Clin Experim 48(9):1120-1127

Rice B, Janssen I, Hudson R, Ross R (1999) Effects of aerobic or resistance exercise and/or diet on glucose tolerance and plasma insulin levels in obese men. Diabetes Care 22(5):684-691. https://doi.org/10.2337/diacare.22.5.684

Roberts BM, Helms ER, Trexler ET, Fitschen PJ (2020) Nutritional recommendations for physique athletes. J Hum Kinet 71:79108. https://doi.org/10.2478/hukin-2019-0096

Robinson SL, Lambeth-Mansell A, Gillibrand G, Smith-Ryan A, Bannock L (2015) A nutrition and conditioning intervention for natural bodybuilding contest preparation. Case study. J Int SocSports Nutr 12:20. https://doi.org/10.1186/s12970-015-0083-x

Rohrig BJ, Pettitt RW, Pettitt CD, Kanzenbach TL (2017) Psychophysiological tracking of a female physique competitor through competition preparation. Int J Exerc Sci 10(2):301-311

Rosa-Caldwell ME, Greene NP (2019) Muscle metabolism and atrophy. Let's talk about sex. Biol Sex Differ 10(1):43. https://doi. org/10.1186/s13293-019-0257-3

Rossetti ML, Steiner JL, Gordon BS (2017) Androgen-mediated regulation of skeletal muscle protein balance. Mol Cell Endocrinol 447:35-44. https://doi.org/10.1016/j.mce.2017.02.031

Rossow LM, Fukuda DH, Fahs CA, Loenneke JP, Stout JR (2013) Natural bodybuilding competition preparation and recovery. A 12-month case study. Int J Sports Physiol Perform 8(5):582-592

Roth C, Rettenmaier L, Behringer M (2021) High-protein energyrestriction: effects on body composition, contractile properties, mood, and sleep in active young college students. Front Sports Active Liv 3:683327. https://doi.org/10.3389/fspor.2021.683327

Ryan AS, Nicklas BJ (2004) Reductions in plasma cytokine levels with weight loss improve insulin sensitivity in overweight and obese postmenopausal women. Diabetes Care 27(7):1699-1705. https:// doi.org/10.2337/diacare.27.7.1699

Sawyer JC, Wood RJ, Davidson PW, Collins SM, Matthews TD, Gregory SM, Paolone VJ (2013) Effects of a short-term carbohydraterestricted diet on strength and power performance. J Strength Cond Res 27(8):2255-2262. https://doi.org/10.1519/JSC.0b013 e31827da314

Scarpelli MC, Nóbrega SR, Santanielo N, Alvarez IF, Otoboni GB, Ugrinowitsch C, Libardi CA (2020) Muscle hypertrophy response is affected by previous resistance training volume in trained individuals. J Strength Cond Res. https://doi.org/10.1519/ JSC.0000000000003558

Schoenfeld BJ, Grgic J (2020) Effects of range of motion on muscle development during resistance training interventions: A systematic review. SAGE Open Med 8:2050312120901559. https://doi. org/10.1177/2050312120901559

Schoenfeld BJ, Contreras B, Krieger J, Grgic J, Delcastillo K, Belliard R, Alto A (2019) Resistance training volume enhances muscle hypertrophy but not strength in trained men. Med Sci Sports Exerc 51(1):94-103. https://doi.org/10.1249/MSS.0000000000 001764

Schoenfeld BJ, Alto A, Grgic J, Tinsley G, Haun CT, Campbell BI, Escalante G, Sonmez GT, Cote G, Francis A, Trexler ET (2020) Alterations in body composition, resting metabolic rate, muscular strength, and eating behavior in response to natural bodybuilding competition preparation: a case study. J Strength Cond Res 34(11):3124-3138. https://doi.org/10.1519/JSC.0000000000 003816

Schoenfeld BJ, Grgic J, Ogborn D, Krieger JW (2017a) Strength and hypertrophy adaptations between Low- vs. high-load resistance training. A systematic review and meta-analysis. J Strength Condition Res 31(12):3508-3523. https://doi.org/10.1519/JSC.00000 00000002200

Schoenfeld BJ, Ogborn D, Krieger JW (2017b) Dose-response relationship between weekly resistance training volume and increases in muscle mass. A systematic review and meta-analysis. J Sports Sci 35(11):1073-1082. https://doi.org/10.1080/02640414.2016. 1210197

Schranner D, Schönfelder M, Römisch-Margl W, Scherr J, Schlegel J, Zelger O, Riermeier A, Kaps S, Prehn C, Adamski J, Söhnlein Q, Stöcker F, Kreuzpointner F, Halle M, Kastenmüller G, Wackerhage H (2021) Physiological extremes of the human blood metabolome: A metabolomics analysis of highly glycolytic, oxidative, and anabolic athletes. Physiol Rep 9(12):e14885. https:// doi.org/10.14814/phy2.14885

Schwartz MW, Seeley RJ, Zeltser LM, Drewnowski A, Ravussin E, Redman LM, Leibel RL (2017) Obesity pathogenesis. an endocrine society scientific statement. Endocr Rev 38(4):267-296. https://doi.org/10.1210/er.2017-00111

Sculthorpe N, Solomon AM, Sinanan ACM, Bouloux P-MG, Grace F, Lewis MP (2012) Androgens affect myogenesis in vitro and increase local IGF-1 expression. Med Sci Sports Exerc 44(4):610-615. https://doi.org/10.1249/MSS.0b013e318237c5c0

Smith GI, Atherton P, Reeds DN, Mohammed BS, Jaffery H, Rankin D, Rennie MJ, Mittendorfer B (2009) No major sex differences in muscle protein synthesis rates in the postabsorptive state and during hyperinsulinemia-hyperaminoacidemia in middle-aged adults. J Appl Physiol (Bethesda, Md. : 1985) 107(4):1308-1315. https://doi.org/10.1152/japplphysiol.00348.2009

Stapley L (2001) Sex differences are more than just hormonal. Trends Endocrinol Metab 12(5):190. https://doi.org/10.1016/S10432760(01)00419-2

Steen SN (1991) Precontest strategies of a male bodybuilder. Int J Sport Nutr 1(1):69-78

Stiegler P, Cunliffe A (2006) The role of diet and exercise for the maintenance of fat-free mass and resting metabolic rate during weight loss. Sports Med (Auckland, N.Z.) 36(3):239-262. https://doi. org/10.2165/00007256-200636030-00005

Stratton MT, Tinsley GM, Alesi MG, Hester GM, Olmos AA, Serafini PR, Modjeski AS, Mangine GT, King K, Savage SN, Webb AT, VanDusseldorp TA (2020) Four weeks of time-restricted feeding combined with resistance training does not differentially influence measures of body composition, muscle performance, resting energy expenditure, and blood biomarkers. Nutrients 12(4):1126. https://doi.org/10.3390/nu12041126

Syed-Abdul MM, Soni DS, Wagganer JD (2019) Effects of self-implemented carbohydrate cycling and moderate to high intensity resistance exercise on body fat in body builders. Gazz Med Ital Arch Sci Med https://doi.org/10.23736/S0393-3660.18.03762-2

Tang JE, Perco JG, Moore DR, Wilkinson SB, Phillips SM (2008) Resistance training alters the response of fed state mixed muscle protein synthesis in young men. Am J Physiol Regul Integr Compar Physiol 294(1):R172-R178. https://doi.org/10.1152/ ajpregu.00636.2007

Terzis G, Spengos K, Mascher H, Georgiadis G, Manta P, Blomstrand E (2010) The degree of p70 S6k and S6 phosphorylation in human skeletal muscle in response to resistance exercise depends on the training volume. Eur J Appl Physiol 110(4):835-843. https://doi.org/10.1007/s00421-010-1527-2 
Tinsley GM, Trexler ET, Smith-Ryan AE, Paoli A, Graybeal AJ, Campbell BI, Schoenfeld BJ (2018) Changes in body composition and neuromuscular performance through preparation, 2 competitions, and a recovery period in an experienced female physique athlete. J Strength Cond Res. https://doi.org/10.1519/JSC.0000000000 002758

Tinsley GM, Forsse JS, Butler NK, Paoli A, Bane AA, La Bounty PM, Morgan GB, Grandjean PW (2017) Time-restricted feeding in young men performing resistance training. A randomized controlled trial. Eur J Sport Sci 17(2):200-207. https://doi.org/10. 1080/17461391.2016.1223173

Tipton KD, Hamilton DL, Gallagher IJ (2018) Assessing the role of muscle protein breakdown in response to nutrition and exercise in humans. Sports Med (Auckland, N.Z.) 48(Suppl 1):53-64. https://doi.org/10.1007/s40279-017-0845-5

Toigo M, Boutellier U (2006) New fundamental resistance exercise determinants of molecular and cellular muscle adaptations. Eur J Appl Physiol 97(6):643-663. https://doi.org/10.1007/ s00421-006-0238-1

Too D, Wakayama EJ, Locati LL, Landwer GE (1998) Effect of a precompetition bodybuilding diet and training regimen on body composition and blood chemistry. J Sports Med Phys Fitness 38(3):245-252

Trabelsi K, Stannard SR, Maughan RJ, Jammoussi K, Zeghal K, Hakim A (2012) Effect of resistance training during Ramadan on body composition and markers of renal function, metabolism, inflammation, and immunity in recreational bodybuilders. Int J Sport Nutr Exerc Metab 22(4):267-275. https://doi.org/10.1123/ijsnem.22.4.267

Trabelsi K, Stannard SR, Ghlissi Z, Maughan RJ, Kallel C, Jamoussi K, Zeghal KM, Hakim A (2013) Effect of fed- versus fasted state resistance training during Ramadan on body composition and selected metabolic parameters in bodybuilders. J Int Soc Sports Nutr 10(1):23. https://doi.org/10.1186/1550-2783-10-23

Trexler ET, Smith-Ryan AE, Norton LE (2014) Metabolic adaptation to weight loss. Implications for the athlete. J Int Soc Sports Nutr 11(1):7. https://doi.org/10.1186/1550-2783-11-7

van der Ploeg GE, Brooks AG, Withers RT, Dollman J, Leaney F, Chatterton BE (2001) Body composition changes in female bodybuilders during preparation for competition. Eur J Clin Nutr 55(4):268-277. https://doi.org/10.1038/sj.ejcn.1601154

Vandenburgh H, Chromiak J, Shansky J, Del Tatto M, Lemaire J (1999) Space travel directly induces skeletal muscle atrophy. FASEB J 13(9):1031-1038

Vargas S, Romance R, Petro JL, Bonilla DA, Galancho I, Espinar S, Kreider RB, Benítez-Porres J (2018) Efficacy of ketogenic diet on body composition during resistance training in trained men. A randomized controlled trial. J Int Soc Sports Nutr 15(1):31. https://doi.org/10.1186/s12970-018-0236-9
Vargas-Molina S, Petro JL, Romance R, Kreider RB, Schoenfeld BJ, Bonilla DA, Benítez-Porres J (2020) Effects of a ketogenic diet on body composition and strength in trained women. J Int Soc Sports Nutr 17(1):19. https://doi.org/10.1186/ s12970-020-00348-7

Vechin FC, Conceição MS, Telles GD, Libardi CA, Ugrinowitsch C (2021) Interference phenomenon with concurrent strength and high-intensity interval training-based aerobic training: an updated model. Sports Med (Auckland, N.Z.) 51(4):599-605. https://doi.org/10.1007/s40279-020-01421-6

Walberg-Rankin J, Edmonds CE, Gwazdauskas FC (1993) Diet and weight changes of female bodybuilders before and after competition. Int J Sport Nutr 3(1):87-102

Waldman HS, Krings BM, Basham SA, Smith JEW, Fountain BJ, McAllister MJ (2018) Effects of a 15-day low carbohydrate, high-fat diet in resistance-trained men. J Strength Cond Res 32(11):3103-3111. https://doi.org/10.1519/JSC.0000000000 002282

Weinheimer EM, Sands LP, Campbell WW (2010) A systematic review of the separate and combined effects of energy restriction and exercise on fat-free mass in middle-aged and older adults. Implications for sarcopenic obesity. Nutr Rev 68(7):375-388. https:// doi.org/10.1111/j.1753-4887.2010.00298.x

West DWD, Kujbida GW, Moore DR, Atherton P, Burd NA, Padzik JP, de Lisio M, Tang JE, Parise G, Rennie MJ, Baker SK, Phillips SM (2009) Resistance exercise-induced increases in putative anabolic hormones do not enhance muscle protein synthesis or intracellular signalling in young men. J Physiol 587(Pt 21):5239_ 5247. https://doi.org/10.1113/jphysiol.2009.177220

Williams T, Walz E, Lane AR, Pebole M, Hackney AC (2015) The effect of estrogen on muscle damage biomarkers following prolonged aerobic exercise in eumenorrheic women. Biol Sport 32(3):193-198. https://doi.org/10.5604/20831862.1150300

Wilson JM, Lowery RP, Roberts MD, Sharp MH, Joy JM, Shields KA, Partl J, Volek JS, D'Agostino D (2017) The effects of ketogenic dieting on body composition, strength, power, and hormonal profiles in resistance training males. J Strength Cond Res. https:// doi.org/10.1519/JSC.0000000000001935

Withers RT, Noell CJ, Whittingham NO, Chatterton BE, Schultz CG, Keeves JP (1997) Body composition changes in elite male bodybuilders during preparation for competition. Aust J Sci Med Sport 29(1):11-16

Publisher's Note Springer Nature remains neutral with regard to jurisdictional claims in published maps and institutional affiliations. 